\title{
Review \\ Gold Nanoclusters as Electrocatalysts for Energy Conversion
}

\author{
Tokuhisa Kawawaki ${ }^{1,2}$ and Yuichi Negishi ${ }^{1,2, *}$ \\ 1 Department of Applied Chemistry, Faculty of Science, Tokyo University of Science, 1-3 Kagurazaka, \\ Shinjuku-ku, Tokyo 162-8601, Japan; kawawaki@rs.tus.ac.jp \\ 2 Photocatalysis International Research Center, Tokyo University of Science, 2641 Yamazaki, Noda, \\ Chiba 278-8510, Japan \\ * Correspondence: negishi@rs.kagu.tus.ac.jp
}

Received: 11 January 2020; Accepted: 27 January 2020; Published: 29 January 2020

\begin{abstract}
Gold nanoclusters ( $\left.\mathrm{Au}_{n} \mathrm{NCs}\right)$ exhibit a size-specific electronic structure unlike bulk gold and can therefore be used as catalysts in various reactions. Ligand-protected $\mathrm{Au}_{n} \mathrm{NCs}$ can be synthesized with atomic precision, and the geometric structures of many $\mathrm{Au}_{n} \mathrm{NCs}$ have been determined by single-crystal X-ray diffraction analysis. In addition, $\mathrm{Au}_{n} \mathrm{NCs}$ can be doped with various types of elements. Clarification of the effects of changes to the chemical composition, geometric structure, and associated electronic state on catalytic activity would enable a deep understanding of the active sites and mechanisms in catalytic reactions as well as key factors for high activation. Furthermore, it may be possible to synthesize $\mathrm{Au}_{n}$ NCs with properties that surpass those of conventional catalysts using the obtained design guidelines. With these expectations, catalyst research using $\mathrm{Au}_{n} \mathrm{NCs}$ as a model catalyst has been actively conducted in recent years. This review focuses on the application of $\mathrm{Au}_{n} \mathrm{NCs}$ as an electrocatalyst and outlines recent research progress.
\end{abstract}

Keywords: gold; cluster; catalyst; hydrogen evolution reaction; oxygen evolution reaction; oxygen reduction reaction; water splitting; fuel cells; alloy; ligand-protected

\section{Introduction}

Gold nanoclusters ( $\mathrm{Au}_{n} \mathrm{NCs}$ ) have physical/chemical properties that differ from those of bulk $\mathrm{Au}$ owing to their size-specific electrical/geometrical structure [1-22]. Therefore, $\mathrm{Au}_{n} \mathrm{NCs}$ have been actively studied since the 1960s from the viewpoints of both basic science and application. Since Brust et al., discovered a method for synthesizing $\mathrm{Au}_{n} \mathrm{NCs}$ protected by thiolate $\left(\mathrm{Au}_{n}(\mathrm{SR})_{m}\right)$ in 1994 [1], researches on $\mathrm{Au}_{n} \mathrm{NCs}$ in particular have grown [6]. $\mathrm{Au}_{n}(\mathrm{SR})_{m} \mathrm{NCs}$ exhibit high stability both in solution and in the solid state because $\mathrm{Au}$ forms a strong bond with SR. In addition, $\mathrm{Au}_{n}(\mathrm{SR})_{m}$ $\mathrm{NCs}$ can be synthesized by simply mixing reagents under the ambient atmosphere. $\mathrm{Au}_{n}(\mathrm{SR})_{m} \mathrm{NCs}$ with these unique characteristics have a low handling threshold even for researchers unfamiliar with the chemical synthesis of metal clusters. $\mathrm{Au}_{n}(\mathrm{SR})_{m} \mathrm{NCs}$ are thus currently one of the most studied metal NCs [1-18]. For these $\mathrm{Au}_{n}(\mathrm{SR})_{m} \mathrm{NCs}$, it became possible to synthesize a series of $\mathrm{Au}_{n}(\mathrm{SR})_{m}$ NCs with atomic precision in 2005 [19]. In addition, since 2007, the geometric structures of many $\mathrm{Au}_{n}(\mathrm{SR})_{m} \mathrm{NCs}$ have been determined through single-crystal X-ray diffraction (SC-XRD) analysis [20]. Since 2009, partial replacement of the Au atoms of $\mathrm{Au}_{n}(\mathrm{SR})_{m} \mathrm{NCs}$ with other elements such as silver $(\mathrm{Ag})$, copper $(\mathrm{Cu})$, platinum $(\mathrm{Pt})$, palladium $(\mathrm{Pd})$, cadmium $(\mathrm{Cd})$, and mercury $(\mathrm{Hg})$ has also been realized [3-5,23-44].

In parallel to these synthesis and structural analysis studies, studies on the functions of $\mathrm{Au}_{n}$ NCs have also been actively conducted. $\mathrm{Au}_{n}$ NCs have been observed to possess catalytic activity for several reactions, including carbon monoxide oxidation [45-55], alcohol oxidation [56-65], 
styrene oxidation [66-70], aromatic compound oxidation [71,72], sulfide oxidation [73-75], and carbon dioxide reduction [76-83]. One of the reasons for these active studies on the catalysis of $\mathrm{Au}_{n} \mathrm{NCs}$ is that their electronic and geometric structures are well understood. Thus, if the obtained catalytic properties are compared with the electronic/geometrical structures of $\mathrm{Au}_{n}(\mathrm{SR})_{m} \mathrm{NCs}$, information on active sites, mechanisms, and key factors for high activation in catalytic reactions can be obtained. With these expectations, $\mathrm{Au}_{n}(\mathrm{SR})_{m} \mathrm{NCs}$ have received great attention as model catalysts [45-83].

In addition, several studies on $\mathrm{Au}_{n}(\mathrm{SR})_{m} \mathrm{NCs}$ as electrocatalysts have also been performed recently. To prevent serious environmental issues including the depletion of fossil fuels and global warming, the establishment of a system in which hydrogen $\left(\mathrm{H}_{2}\right)$ is generated from water and solar energy using a photocatalyst is desired, with the generated $\mathrm{H}_{2}$ used for the generation of electricity using fuel cells $[84,85]$. Once such an energy conversion system is established, it will be possible to circulate an energy medium $\left(\mathrm{H}_{2}\right)$ in addition to obtaining electricity only from solar energy and abundant water resources. However, realization of such an ultimate energy conversion system requires further improvement of the reaction efficiency of each half reaction of water splitting and fuel cells, including the hydrogen evolution reaction (HER), oxygen evolution reaction (OER), hydrogen oxidation reaction (HOR), and oxygen reduction reaction (ORR; Figure $1 \mathrm{~A})$.

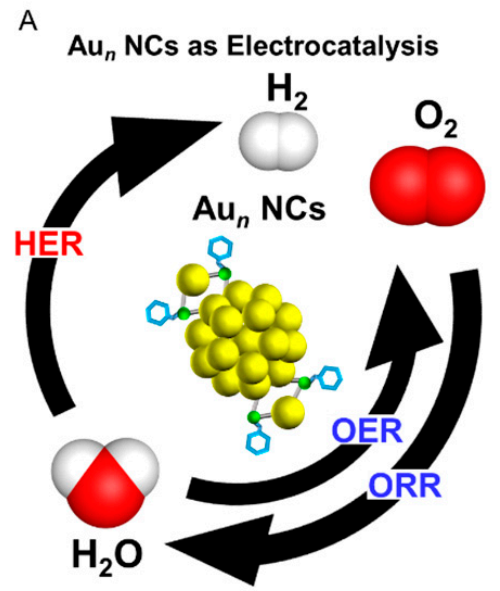

B

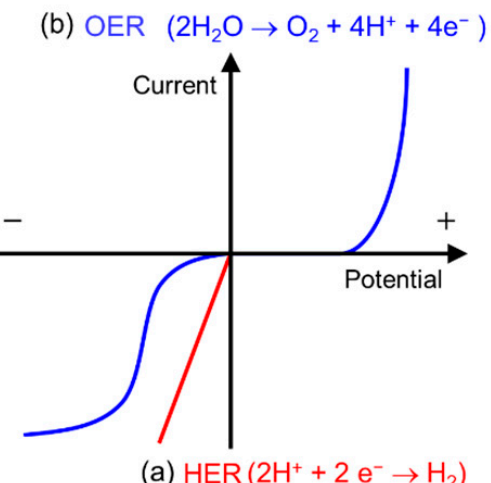

(c) $\operatorname{ORR}\left(\mathrm{O}_{2}+4 \mathrm{H}^{+}+4 \mathrm{e}^{-} \rightarrow 2 \mathrm{H}_{2} \mathrm{O}\right)$

Figure 1. (A) Schematic illustration of gold nanoclusters ( $\left.\mathrm{Au}_{n} \mathrm{NCs}\right)$ for an electrocatalytic reaction in water splitting (hydrogen evolution reaction (HER) and oxygen evolution reaction (OER)) and fuel cells (oxygen reduction reaction (ORR)). (B) Current-potential characteristics for (a) HER, (b) OER, and (c) ORR.

To improve the reactivity per unit volume, it is necessary to increase the specific surface area of the active sites and increase the reaction rate at the active sites. For the former, size reduction of the catalyst is one effective method. However, the latter is strongly related to the adsorption energy of reactive molecules on the catalyst surface. The activity of the chemical reaction on the catalyst surface is the highest when the Gibbs energy of adsorption between the catalyst and reactant is moderate according to the Sabatier principle [86]. This is because the reaction does not occur without the adsorption of reactants but is inhibited by the strong adsorption of reactants. Therefore, the relationship between the reaction efficiency and the Gibbs energy for the adsorption of reactants follows a curved line called an activity volcano plot [87]. Fine nanoparticle catalysts suitable for the HER [88-92], OER [93-95], and ORR [96-101] have been developed based on theoretical predictions of activity volcano plots using various metals and alloy nanoparticles (NPs). $\mathrm{Au}_{n} \mathrm{NCs}$ have recently been observed to possess catalytic activity for the HER, OER, and ORR [77,102-116] (Figure 1). Therefore, $\mathrm{Au}_{n} \mathrm{NCs}$ are expected to become a model catalyst even in such an energy conversion system. A better understanding of the correlation between electronic/geometrical structures and the catalytic activity of the HER, OER, and ORR in $\mathrm{Au}_{n}$ NCs might lead to the discovery of new key factors for achieving high activation. Furthermore, because $\mathrm{Au}_{n} \mathrm{NCs}$ are composed of several tens of atoms or less, the use of fine $\mathrm{Au}_{n} \mathrm{NCs}$ 
as a catalyst is also effective in reducing the consumption of expensive noble metals. Thus, it may be possible to create HER, OER, and ORR catalysts with properties that surpass those of conventional catalysts using these unique characteristics of $A u_{n}$ NCs. With these expectations, several groups are conducting research on the application of $A u_{n}$ NCs as electrocatalysts. This article reviews the basic theory of electrocatalysts and recent research on HER, OER, and ORR catalysts using Au $\mathrm{u}_{n}$ NCs and their alloy NCs.

\section{Electrocatalytic Reaction in Water Splitting}

$\mathrm{H}_{2}$ is expected to be an important energy source to support a sustainable energy society. Currently, $\mathrm{H}_{2}$ is generated as a by-product during steam reforming or coke production. However, if a water-splitting reaction using an electrocatalyst can be applied for hydrogen production, the large-scale facility of the current system would not be required. In addition, it would be possible to produce $\mathrm{H}_{2}$ only with water and electricity using the surplus power from a power plant. Therefore, water electrolysis is considered one of the cleanest energy production reactions for a sustainable energy society.

The water-splitting reaction consists of two half reactions, the HER and OER. When a voltage is applied to the metal electrode, a reduction reaction proceeds at the cathode and an oxidation reaction proceeds at the anode, resulting in the decomposition of water molecules into $\mathrm{H}_{2}$ and $\mathrm{O}_{2}$ at each electrode. However, the reactions do not proceed even if a potential equal to or higher than both the oxidation and reduction potentials in each reaction (HER: $0 \mathrm{~V}$ vs. SHE, OER: 1.23 V vs. SHE; SHE = standard hydrogen electrode) is applied to the electrode. This is because the activation energy of each reaction is too high. Therefore, noble metal NPs are used as a catalyst to reduce the activation energy of the reaction.

\subsection{Hydrogen Evolution Reaction}

In the HER, metal surface atoms of the catalyst form bonding orbitals with protons $\left(\mathrm{H}^{+}\right)$through the Volmer-Heyrovsky or Volmer-Tafel mechanism, producing molecular hydrogen [117].

Under acidic conditions, the following reactions occur:

$$
\begin{gathered}
\text { Volmer reaction: } \mathrm{M}+\mathrm{H}^{+}+\mathrm{e}^{-} \rightarrow \mathrm{M}-\mathrm{H} \\
\text { Heyrovsky reaction: } \mathrm{M}-\mathrm{H}+\mathrm{H}^{+}+\mathrm{e}^{-} \rightarrow \mathrm{M}-\mathrm{H}_{2} \\
\text { Tafel reaction: } 2 \mathrm{M}-\mathrm{H} \rightarrow 2 \mathrm{M}+\mathrm{H}_{2}
\end{gathered}
$$

However, under alkaline conditions, the following reactions occur:

$$
\begin{aligned}
& \text { Volmer reaction: } 2 \mathrm{M}+2 \mathrm{H}_{2} \mathrm{O}+2 \mathrm{e}^{-} \rightarrow 2 \mathrm{M}-\mathrm{H}+2 \mathrm{OH}^{-} \\
& \text {Heyrovsky reaction: } \mathrm{M}-\mathrm{H}+\mathrm{H}_{2} \mathrm{O}+\mathrm{e}^{-} \rightarrow \mathrm{M}-\mathrm{H}_{2}+\mathrm{OH}^{-} \\
& \text {Tafel reaction: } 2 \mathrm{M}-\mathrm{H} \rightarrow 2 \mathrm{M}+\mathrm{H}_{2}
\end{aligned}
$$

Bulk Au possesses almost no HER activity, whereas $\mathrm{Au}_{n}(\mathrm{SR})_{m}$ NCs possess HER activity. In addition, their activity can be further improved by doping $\mathrm{Au}_{n}(\mathrm{SR})_{m} \mathrm{NCs}$ with appropriate heterogeneous elements. These effects were reported by Lee and Jiang et al., in 2017 [102]. They evaluated the HER activity using linear sweep voltammetry (LSV) in tetrahydrofuran (THF) solution with 1.0 M trifluoroacetic acid (TFA) and $0.1 \mathrm{M}$ tetrabutylammonium hexafluorophosphate $\left(\mathrm{Bu}_{4} \mathrm{NPF}_{6}\right)$ in the absence (black) and presence of $\mathrm{Au}_{25}\left(\mathrm{SC}_{6} \mathrm{H}_{13}\right)_{18}$ or $\mathrm{Au}_{24} \mathrm{Pt}\left(\mathrm{SC}_{6} \mathrm{H}_{13}\right)_{18}\left(\mathrm{SC}_{6} \mathrm{H}_{13}=\right.$ 1-hexanethiolate) on a glassy carbon electrode (GCE). The onset potential of the HER (Figure 1B(a)) occurred at $-1.25 \mathrm{~V}$ for the GCE blank (Figure 2A, black line), whereas it occurred at $-1.1 \mathrm{~V}$ for the GCE with $\mathrm{Au}_{25}\left(\mathrm{SC}_{6} \mathrm{H}_{13}\right)_{18}$ (Figure 2A, red line). In addition, for the GCE with $\mathrm{Au}_{24} \mathrm{Pt}\left(\mathrm{SC}_{6} \mathrm{H}_{13}\right)_{18}$, the onset potential of the HER was further reduced to $-0.89 \mathrm{~V}$ (Figure 2A, blue line). These findings indicated that $\mathrm{Au}_{n}(\mathrm{SR})_{m} \mathrm{NCs}$ has catalytic activity for the HER and that the HER activity can be further 
improved by substituting one $\mathrm{Au}$ atom of the $\mathrm{Au}_{n}(\mathrm{SR})_{m} \mathrm{NCs}$ with a Pt atom (Table 1). They estimated the HER energies of $\mathrm{Au}_{25}\left(\mathrm{SCH}_{3}\right)_{18}$ and $\mathrm{Au}_{24} \mathrm{Pt}\left(\mathrm{SCH}_{3}\right)_{18}\left(\mathrm{SCH}_{3}=\right.$ methanethiolate) using density functional theory (DFT) calculations to elucidate the reasons for this behavior (Figure 2C). In these DFT calculations, $\mathrm{H}^{+}$solvated by two THF molecules was used as $\mathrm{H}^{+}$. The resulting energy change in the Volmer step was $0.539 \mathrm{eV}$ for $\left[\mathrm{Au}_{25}\left(\mathrm{SCH}_{3}\right)_{18}\right]^{-}$, indicating that this reaction is endothermic. However, the energy change in the Volmer step was $-0.059 \mathrm{eV}$ for $\left[\mathrm{Au}_{24} \mathrm{Pt}\left(\mathrm{SCH}_{3}\right)_{18}\right]^{2-}$, indicating that there is almost no energy change (Figure $2 \mathrm{C}$, step 1). The higher HER activity of $\mathrm{Au}_{24} \mathrm{Pt}\left(\mathrm{SC}_{6} \mathrm{H}_{13}\right)_{18}$ was

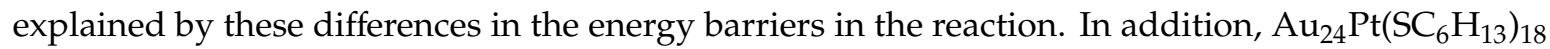
possessed higher HER activity even compared with Pt NPs, which are highly active materials for the HER (Figure 2B).

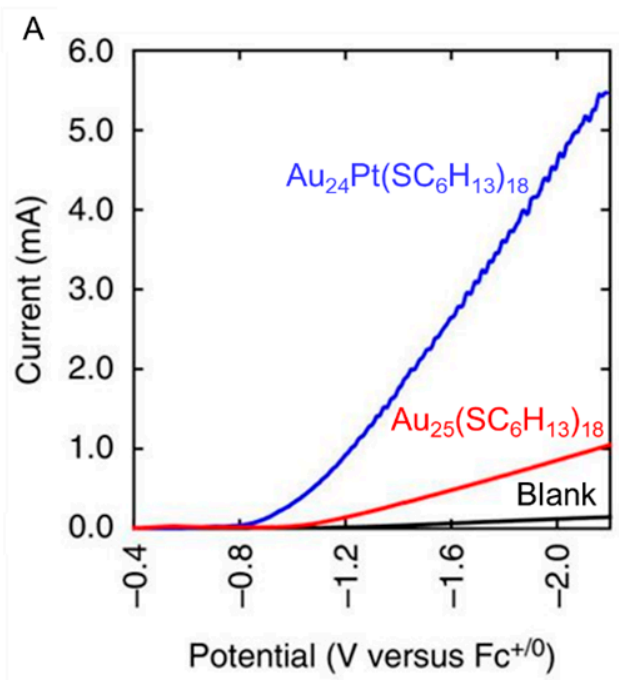

C

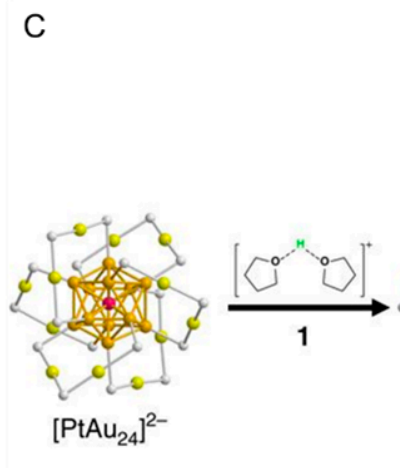

$\left[\mathrm{H}-\mathrm{PtAu}{ }_{24}\right]^{-}$ $\Delta E_{1}=-0.059 \mathrm{eV}$
B

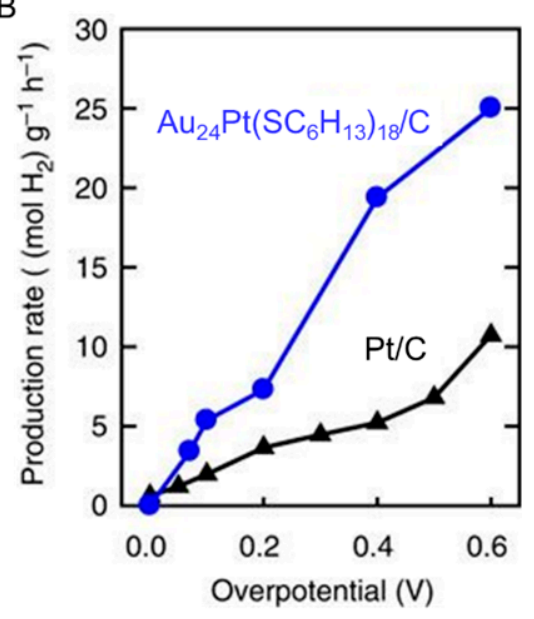

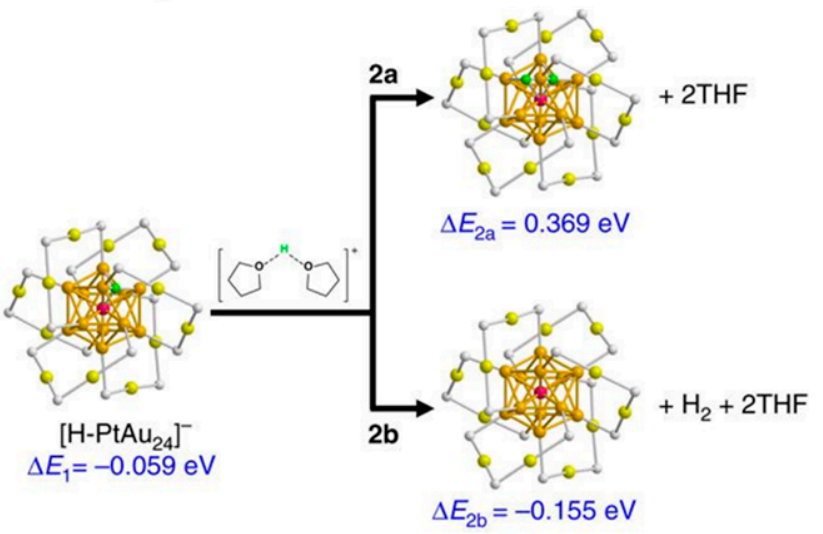

Figure 2. (A) HER polarization curves of $\mathrm{Au}_{25}\left(\mathrm{SC}_{6} \mathrm{H}_{13}\right)_{18}$ - or $\mathrm{Au}_{24} \mathrm{Pt}\left(\mathrm{SC}_{6} \mathrm{H}_{13}\right)_{18}$-adsorbed glassy carbon electrode (GCE), or GCE. (B) $\mathrm{H}_{2}$ production rates per mass of metals in the catalyst of $\mathrm{Au}_{24} \mathrm{Pt}\left(\mathrm{SC}_{6} \mathrm{H}_{13}\right)_{18} / \mathrm{C}$ (blue circles) and $\mathrm{Pt} / \mathrm{C}$ (black triangles) electrodes. (C) DFT calculation results for $\mathrm{Au}_{24} \mathrm{Pt}\left(\mathrm{SCH}_{3}\right)_{18}$. Color code: golden $=\mathrm{Au}$ core; olive $=\mathrm{Au}$ shell; purple $=\mathrm{Pt}$; green $=$ adsorbed $\mathrm{H}$ from the liquid medium; grey $=$ S. Panels $(\mathbf{A}-\mathbf{C})$ are reproduced with permission from reference [102]. Copyright Springer Nature, 2017.

Lee and Jiang et al., observed that a high HER activity and a high catalyst turnover frequency (TOF) can be achieved by doping $\mathrm{Au}_{25}\left(\mathrm{SC}_{6} \mathrm{H}_{13}\right)_{18}$ with not only Pt but also Pd $\left(\mathrm{Au}_{24} \mathrm{Pt}\left(\mathrm{SC}_{6} \mathrm{H}_{13}\right)_{18}\right.$ $\left.>\mathrm{Au}_{24} \mathrm{Pd}\left(\mathrm{SC}_{6} \mathrm{H}_{13}\right)_{18}>\mathrm{Au}_{25}\left(\mathrm{SC}_{6} \mathrm{H}_{13}\right)_{18}\right)$ [103]. They reported that TOF values of $\mathrm{Au}_{25}\left(\mathrm{SC}_{6} \mathrm{H}_{13}\right)_{18}$, $\mathrm{Au}_{24} \mathrm{Pd}\left(\mathrm{SC}_{6} \mathrm{H}_{13}\right)_{18}$, and $\mathrm{Au}_{24} \mathrm{Pt}_{2}\left(\mathrm{SC}_{6} \mathrm{H}_{13}\right)_{18}$ were 8.2, 13.0, and $33.3 \mathrm{~mol} \mathrm{H}_{2}$ (mol catalyst) ${ }^{-1} \mathrm{~s}^{-1}$ at $-0.60 \mathrm{~V}$ vs. the reversible hydrogen electrode (RHE), respectively. In addition, it was revealed that the doping of $\mathrm{Au}_{38}(\mathrm{SR})_{24}$ with different elements results in a similar activity enhancement effect with $\mathrm{Au}_{25}\left(\mathrm{SC}_{6} \mathrm{H}_{13}\right)_{18}$ 
$\left(\mathrm{Au}_{36} \mathrm{Pt}_{2}\left(\mathrm{SC}_{6} \mathrm{H}_{13}\right)_{24}>\mathrm{Au}_{36} \mathrm{Pd}_{2}\left(\mathrm{SC}_{6} \mathrm{H}_{13}\right)_{24}>\mathrm{Au}_{38}\left(\mathrm{SC}_{6} \mathrm{H}_{13}\right)_{24}\right)$ [103]. These results are in good agreement with the DFT calculation results. In addition to these studies, Jiang et al., also investigated the doping effects of various elements (Pt, $\mathrm{Pd}, \mathrm{Ag}, \mathrm{Cu}, \mathrm{Hg}$, and $\mathrm{Cd})$ in $\mathrm{Au}_{25}\left(\mathrm{SCH}_{3}\right)_{18}$ using DFT calculations [105]. The results predicted that $\mathrm{Au}_{24} \mathrm{Pt}\left(\mathrm{SCH}_{3}\right)_{18}, \mathrm{Au}_{24} \mathrm{Pd}\left(\mathrm{SCH}_{3}\right)_{18}$, and $\mathrm{Au}_{24} \mathrm{Cu}\left(\mathrm{SCH}_{3}\right)_{18}$, in which the heteroatom $(\mathrm{Pt}, \mathrm{Pd}$, or $\mathrm{Cu})$ is located at the center of the metal core, have a higher HER activity than $\mathrm{Au}_{25}\left(\mathrm{SCH}_{3}\right)_{18}$. Zhu et al., reported that another fine alloy $\mathrm{NC}, \mathrm{Au}_{2} \mathrm{Pd}_{6}\left(\mathrm{~S}_{4}\left(\mathrm{PPh}_{3}\right)_{4}\left(\mathrm{PhF}_{2} \mathrm{~S}\right)_{6}\right)\left(\mathrm{PPh}_{3}=\right.$ triphenylphosphine, $\mathrm{PhF}_{2} \mathrm{~S}=3$,4-difluorobenzenethiolate), also exhibits HER activity (Table 1) [106]. These studies revealed that $\mathrm{Au}_{n}(\mathrm{SR})_{m}$ and their alloy NCs have HER activity and it can be improved by controlling the electronic structure of $\mathrm{Au}_{n} \mathrm{NCs}$ through heteroatom doping.

Table 1. Representative references on HER activity of $\mathrm{Au}_{n} \mathrm{NCs}$ and related alloy NCs.

\begin{tabular}{|c|c|c|c|c|}
\hline Ligand & Support & Experimental Condition & Activity & Reference \\
\hline $\mathrm{SC}_{6} \mathrm{H}_{13}$ & - & 1.0 M TFA and $0.1 \mathrm{M} \mathrm{Bu}_{4} \mathrm{NPF}_{6}$ in $\mathrm{THF}^{c}$ & $\mathrm{Au}_{24} \mathrm{Pt}\left(\mathrm{SC}_{6} \mathrm{H}_{13}\right)_{18}>\mathrm{Au}_{25}\left(\mathrm{SC}_{6} \mathrm{H}_{13}\right)_{18}$ & [102] \\
\hline $\mathrm{SC}_{6} \mathrm{H}_{13}$ & carbon black & $\begin{array}{l}1 \mathrm{M} \text { Britton-Robinson buffer solution in } 2 \\
\mathrm{M} \mathrm{KCl} \mathrm{aq} \mathrm{(pH} 3)^{c, d}\end{array}$ & $\begin{array}{c}\mathrm{Au}_{24} \mathrm{Pt}\left(\mathrm{SC}_{6} \mathrm{H}_{13}\right)_{18}>\mathrm{Au}_{24} \mathrm{Pd}\left(\mathrm{SC}_{6} \mathrm{H}_{13}\right)_{18}> \\
\mathrm{Au}_{25}\left(\mathrm{SC}_{6} \mathrm{H}_{13}\right)_{18}\end{array}$ & [103] \\
\hline $\mathrm{SC}_{6} \mathrm{H}_{13}$ & carbon black & $\begin{array}{c}1 \mathrm{M} \text { Britton-Robinson buffer solution in } 2 \\
\mathrm{M} \mathrm{KCl} \mathrm{aq} \mathrm{(pH} \mathrm{3)}\end{array}$ & $\begin{array}{c}\mathrm{Au}_{36} \mathrm{Pt}_{2}\left(\mathrm{SC}_{6} \mathrm{H}_{13}\right)_{24}>\mathrm{Au}_{36} \mathrm{Pd}_{2}\left(\mathrm{SC}_{6} \mathrm{H}_{13}\right)_{24}> \\
\mathrm{Au}_{38}\left(\mathrm{SC}_{6} \mathrm{H}_{13}\right)_{24}\end{array}$ & [103] \\
\hline $\begin{array}{l}\mathrm{PPh}_{3} \\
\mathrm{PPh}_{2}{ }^{a} \\
\mathrm{Cl}^{b} \\
\mathrm{PhF}_{2} \mathrm{~S}\end{array}$ & $\mathrm{MoS}_{2}$ & $0.5 \mathrm{M}$ phosphate buffer solution ( $\mathrm{pH}$ 6.7) ${ }^{c, d}$ & $\begin{array}{c}\mathrm{Au}_{2} \mathrm{Pd}_{6}\left(\mathrm{~S}_{4}\left(\mathrm{PPh}_{3}\right)_{4}\left(\mathrm{PhF}_{2} \mathrm{~S}\right)_{6}\right) / \mathrm{MoS}_{2}>\text { Mixture of } \\
\mathrm{Au}_{2} \mathrm{Cl} \mathrm{Cl}_{2} \mathrm{C}\left(\mathrm{PPh}_{2}\right)_{2} \text { and } \mathrm{Pd}_{3}\left(\mathrm{Cl}\left(\mathrm{PPh}_{2}\right)_{2}\left(\mathrm{PPh}_{3}\right)_{3}\right) / \mathrm{MoS}_{2}> \\
\mathrm{Pd}_{3}\left(\mathrm{Cl}\left(\mathrm{PPh}_{2}\right)_{2}\left(\mathrm{PPh}_{3}\right)_{3}\right) / \mathrm{MoS}_{2}> \\
\mathrm{Au}_{2} \mathrm{Cl}_{2} \mathrm{C}\left(\mathrm{PPh}_{2}\right)_{2} / \mathrm{MoS}_{2}>\mathrm{MoS}_{2}\end{array}$ & [104] \\
\hline $\begin{array}{l}\text { porphyrin } \mathrm{SC}_{1} \mathrm{P} \\
\text { porphyrin } \mathrm{SC}_{2} \mathrm{P} \\
\text { PET }\end{array}$ & - & $0.5 \mathrm{M} \mathrm{H}_{2} \mathrm{SO}_{4} \mathrm{aq}^{e}$ & $\begin{array}{c}\mathrm{Au}(1.3 \mathrm{~nm})\left(\text { porphyrin } \mathrm{SC}_{1} \mathrm{P}\right)>\mathrm{Au}(1.3 \\
\mathrm{nm})\left(\text { porphyrin } \mathrm{SC}_{2} \mathrm{P}\right)>\mathrm{Au}(1.3 \mathrm{~nm})(\mathrm{PET})\end{array}$ & [107] \\
\hline $\begin{array}{l}\text { PET } \\
\text { SePh }\end{array}$ & $\mathrm{MoS}_{2}$ & $0.5 \mathrm{M} \mathrm{H}_{2} \mathrm{SO}_{4} \mathrm{aq}^{c, d}$ & $\mathrm{Au}_{25}(\mathrm{PET})_{18} / \mathrm{MoS}_{2}>\mathrm{Au}_{25}(\mathrm{SePh})_{18} / \mathrm{MoS}_{2}>\mathrm{MoS}_{2}$ & [108] \\
\hline $\begin{array}{l}\mathrm{SC}_{6} \mathrm{H}_{13} \\
\text { MPA } \\
\text { MPS }\end{array}$ & - & $0.1 \mathrm{M} \mathrm{KCl} \mathrm{aq}{ }^{c}$ & $\begin{array}{c}\mathrm{Au}_{24} \mathrm{Pt}(\mathrm{MPS})_{18}>\mathrm{Au}_{25}(\mathrm{MPS})_{18}>\mathrm{Au}_{25}(\mathrm{MPA})_{18}> \\
\mathrm{Au}_{25}\left(\mathrm{SC}_{6} \mathrm{H}_{13}\right)_{18}\end{array}$ & [109] \\
\hline
\end{tabular}

${ }^{a}$ Diphenylphosphine. ${ }^{b}$ Chlorine. ${ }^{c}$ WE: Working electrode; GCE. ${ }^{d}$ WE: Containing Nafion. ${ }^{e}$ WE: Carbon tape.

The HER activity varies depending not only on the chemical composition of the metal core but also on the properties of the ligand. In 2018, Teranishi and Sakamoto et al., used $\mathrm{Au}_{n} \mathrm{NCs}$ coordinated with SR-containing porphyrin (porphyrin $\mathrm{SC}_{x} \mathrm{P}$ ). They investigated the effects of the ligand structure on the HER activity of $\mathrm{Au}_{n}(\mathrm{SR})_{m} \mathrm{NCs}$ [107]. In these clusters, the porphyrin ring coordinates horizontally to the gold core. Then, the distance between the porphyrin ring and the Au surface was controlled by changing the length of the alkyl chain between the porphyrin ring and the acetylthio group (Figure $3 \mathrm{~A}, \mathrm{C}$ ) $[118,119]$. The alkyl chain is a methylene chain for porphyrin $\mathrm{SC}_{1} \mathrm{P}$ and an ethylene chain for porphyrin $\mathrm{SC}_{2} \mathrm{P}$. The distance between the porphyrin ring and the acetylthio group was determined to be $3.4 \AA$ for porphyrin $\mathrm{SC}_{1} \mathrm{P}$ and $4.9 \AA$ for porphyrin $\mathrm{SC}_{2} \mathrm{P}$ by SC-XRD analysis. The researchers synthesized three sizes of $\mathrm{Au}_{n} \mathrm{NCs}$ with a core size of approximately 1.3, 2.2, or $3.8 \mathrm{~nm}$ using porphyrin $\mathrm{SC}_{1} \mathrm{P}$, porphyrin $\mathrm{SC}_{2} \mathrm{P}$, or a common protective ligand, 2-phenylethanethiolate (PET). Transmission electron microscope (TEM) images of the synthesized $\mathrm{Au}_{n}(\mathrm{SR})_{m} \mathrm{NCs}(\mathrm{SR}=$ porphyrin $\mathrm{SC}_{1} \mathrm{P}$, porphyrin $\mathrm{SC}_{2} \mathrm{P}$, or $\mathrm{PET}$ ) with a core size of approximately $1.3 \mathrm{~nm}$ are presented in Figure $3 \mathrm{~B}, \mathrm{D}, \mathrm{F}$, respectively. Among these products, matrix-assisted laser desorption/ionization mass spectrometry indicated that $\mathrm{Au}_{n}$ (porphyrin $\left.\mathrm{SC}_{1} \mathrm{P}\right)_{m} \mathrm{NC}$ consisted of $77 \mathrm{Au}$ atoms and 8 porphyrin $\mathrm{SC}_{1} \mathrm{P}$ molecules and $\mathrm{Au}_{n}$ (porphyrin $\left.\mathrm{SC}_{2} \mathrm{P}\right)_{m} \mathrm{NC}$ s consisted of $75 \mathrm{Au}$ atoms and 11 porphyrin $\mathrm{SC}_{2} \mathrm{P}$ molecules. The effects of the ligand structure and $\mathrm{Au}$ core size on the HER activity of $\mathrm{Au}_{n}(\mathrm{SR})_{m} \mathrm{NCs}$ were investigated using the obtained nine types of $\mathrm{Au}_{n}(\mathrm{SR})_{m} \mathrm{NCs}$. As a result, in $\mathrm{Au}_{n}(\mathrm{SR})_{m}$ NCs with a core size of approximately $1.3 \mathrm{~nm}, \mathrm{Au}_{n}$ (porphyrin $\left.\mathrm{SC}_{1} \mathrm{P}\right)_{m}$ and $\mathrm{Au}_{n}$ (porphyrin $\left.\mathrm{SC}_{2} \mathrm{P}\right)_{m}$ NCs exhibited higher current densities of the HER than $\mathrm{Au}_{n}(\mathrm{PET})_{m} \mathrm{NCs}$ (Table 1). For instance, $\mathrm{Au}_{n}$ (porphyrin $\left.\mathrm{SC}_{1} \mathrm{P}\right)_{m} \mathrm{NCs}$ resulted in a 4.6 times higher current density of the HER than $\mathrm{Au}_{n}(\mathrm{PET})_{m} \mathrm{NCs}$ at $-0.4 \mathrm{~V}$ vs. RHE. In addition, using $\mathrm{Au}_{n}$ (porphyrin $\left.\mathrm{SC}_{1} \mathrm{P}\right)_{m} \mathrm{NCs}$, the HER occurred at a smaller overvoltage than using $\mathrm{Au}_{n}$ (porphyrin $\left.\mathrm{SC}_{2} \mathrm{P}\right)_{m} \mathrm{NCs}$. These results indicate that the HER activity of $\mathrm{Au}_{n} \mathrm{NCs}$ depends on the type of ligand and the distance between the ligand and the metal core in $\mathrm{Au}_{n} \mathrm{NCs}$ [107]. In this work, the $\mathrm{Au}_{n}(\mathrm{SR})_{m} \mathrm{NCs}$ with a core size of approximately $2.2 \mathrm{~nm}$ showed higher catalytic activity than those with a core size of approximately $1.3 \mathrm{~nm}$ (Figure 3G,H). This size dependence of the catalytic activity is a little strange considering the surface area of the metal core because a reduction of a core size of 
$\mathrm{Au}_{n}(\mathrm{SR})_{m}$ NCs typically leads to the increase in the surface area of Au metal core, which are active sites in HER. The authors have not discussed the details on this point in this paper probably due to the difficulty in precisely estimating the surface area of each $\mathrm{Au}_{n}(\mathrm{SR})_{m} \mathrm{NCs}$.

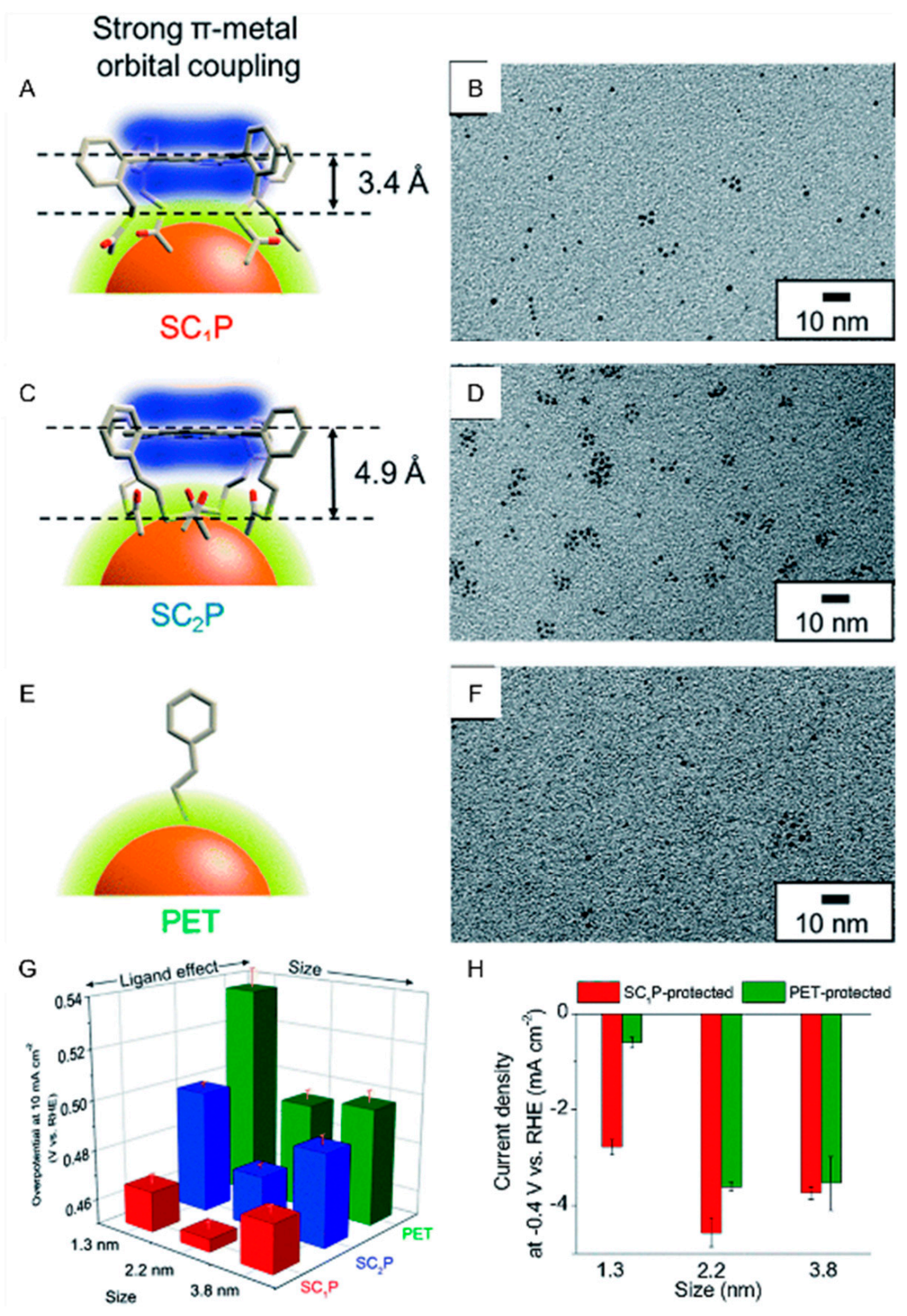

Figure 3. (A,C,E) Schematic illustration of coordination of ligands: (A) porphyrin $\mathrm{SC}_{1} \mathrm{P},(\mathrm{C})$ porphyrin $\mathrm{SC}_{2} \mathrm{P}$, and (E) PET. (B,D,F) TEM images of Au NCs with a core size of approximately $1.3 \mathrm{~nm}$ protected by porphyrin $\mathrm{SC}_{1} \mathrm{P}$, porphyrin $\mathrm{SC}_{2} \mathrm{P}$, or $\mathrm{PET}$, respectively. (G) Comparison of overpotential at $-10 \mathrm{~mA} \mathrm{~cm}^{-2}$ and $(\mathbf{H})$ current density at $-0.4 \mathrm{~V}$ of each size of Au NCs protected with each ligand. Panels $(\mathbf{A}-\mathbf{H})$ are reproduced with permission from reference [107]. Copyright Royal Society of Chemistry, 2018.

The property of the ligand also strongly affects the interaction between $\mathrm{Au}_{n}(\mathrm{SR})_{m} \mathrm{NCs}$ and the electrode as well as the affinity between $\mathrm{Au}_{n}(\mathrm{SR})_{m}$ NCs and water molecules. Lee and Jiang et al., synthesized $\mathrm{Au}_{n}(\mathrm{SR})_{m} \mathrm{NCs}$ with $\mathrm{SC}_{6} \mathrm{H}_{13}$, 3-mercaptopropionic acid (MPA), or 3-mercapto-1-propanesulfonic acid (MPS; Figure $4 \mathrm{~B})$ as a ligand $\left(\mathrm{Au}_{25}\left(\mathrm{SC}_{6} \mathrm{H}_{13}\right)_{18}, \mathrm{Au}_{25}(\mathrm{MPA})_{18}\right.$, and $\left.\mathrm{Au}_{25}(\mathrm{MPS})_{18}\right)$ and used them to investigate the effect of ligand properties on the HER activity [109]. In the experiment, $\mathrm{Au}_{25}\left(\mathrm{SC}_{6} \mathrm{H}_{13}\right)_{18}, \mathrm{Au}_{25}(\mathrm{MPA})_{18}$, or $\mathrm{Au}_{25}(\mathrm{MPS})_{18}$ was dissolved at a concentration of 
$1 \mathrm{mM}$ in $0.1 \mathrm{M} \mathrm{KCl}$ aqueous solution, and LSV measurements were performed using a GCE $\left(50 \mathrm{mV} \mathrm{s}^{-1}\right)$. Although the blank current was $0.01 \mathrm{~mA}$ at $-0.7 \mathrm{~V}$ vs. RHE (Figure $4 \mathrm{C}$, black line), the HER current of the sample including $\mathrm{Au}_{25}(\mathrm{MPA})_{18}$ increased up to $0.13 \mathrm{~mA}$ at $-0.7 \mathrm{~V}$ vs. RHE (Figure $4 \mathrm{C}$, red line). When $\mathrm{Au}_{25}(\mathrm{MPS})_{18}$ was used, a higher HER current of $1.0 \mathrm{~mA}$ was observed at $-0.7 \mathrm{~V}$ vs. RHE (Figure 4C, blue line). MPS and MPA have a hydrophilic functional group (sulfonic acid or carboxylic acid group, respectively) unlike $\mathrm{SC}_{6} \mathrm{H}_{13}$. These hydrophilic functional groups have the property of releasing $\mathrm{H}^{+}$in an aqueous solution. In addition, the sulfonic acid group of MPS ( $\mathrm{pKa}<1$ ) is expected to have higher $\mathrm{H}^{+}$releasing ability than the carboxylic acid group of MPA ( $\mathrm{pKa}=3.7$ ). For these reasons, it was interpreted that the difference in the HER activity described above is largely related to the difference in the $\mathrm{H}^{+}$releasing ability of these ligands (Table 1). It was speculated that the energy barrier associated with the intermolecular and intramolecular $\mathrm{H}^{+}$transfer steps is lowered by $\mathrm{H}^{+}$ relay in $\mathrm{Au}_{n} \mathrm{NCs}$ with high HER activity (Figure 4A). In this paper, they also reported that the use of $\mathrm{Au}_{24} \mathrm{Pt}(\mathrm{MPS})_{18}$, in which $\mathrm{Au}_{25}(\mathrm{MPS})_{18}$ is replaced with $\mathrm{Pt}$, results in even higher HER activity than $\mathrm{Au}_{25}(\mathrm{MPS})_{18}$ (Figure 4D and Table 1). They descried that the TOF value of $\mathrm{Au}_{24} \mathrm{Pt}(\mathrm{MPS})_{18}$ was $127 \mathrm{~mol}$ $\mathrm{H}_{2}$ (mol catalyst) ${ }^{-1} \mathrm{~s}^{-1}$, which was 4 times higher than that of $\mathrm{Au}_{25}(\mathrm{MPS})_{18}$ at $-0.7 \mathrm{~V}$ vs. RHE.
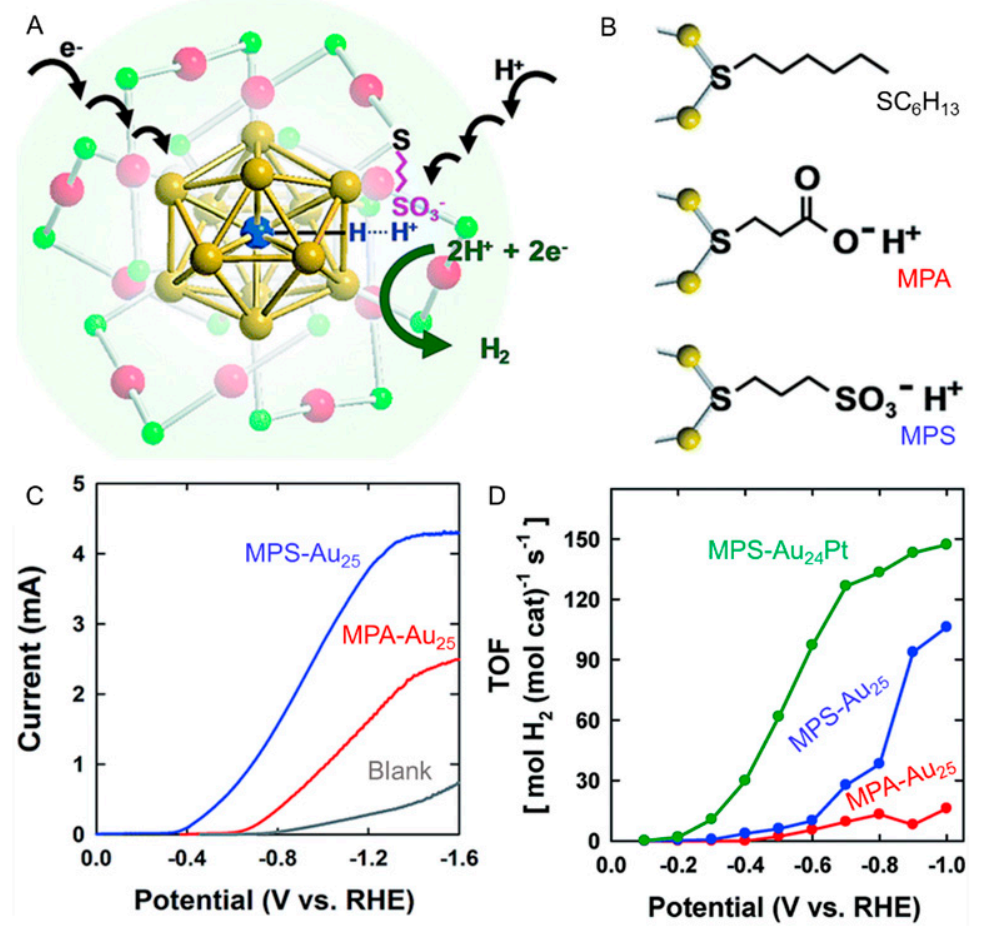

Figure 4. (A) Schematic illustration of proton relay mechanism of $\mathrm{Au}_{24} \mathrm{Pt}(\mathrm{SR})_{18}$ nanocluster for formation of $\mathrm{H}_{2}$ and (B) ligand structures: $\mathrm{SC}_{6} \mathrm{H}_{13}$, MPA, and MPS. Color codes: blue = Pt; golden = core $\mathrm{Au}$; red = shell $\mathrm{Au}$; and green = S. (C) HER polarization curves in $0.1 \mathrm{M} \mathrm{KCl}$ aqueous solution containing $180 \mathrm{mM}$ acetic acid for MPA-Au 25 (red) or MPS-Au 25 (blue). (D) turnover frequencies (TOFs) obtained at various potentials in water $(3.0 \mathrm{M} \mathrm{KCl})$ containing $180 \mathrm{mM}$ HOAc for MPA-Au $\mathrm{Au}_{25}$ (red), MPS- $\mathrm{Au}_{25}$ (blue), or MPS- $\mathrm{Au}_{24} \mathrm{Pt}$ (green). Panels $(\mathrm{A}-\mathrm{D})$ are reproduced with permission from reference [109]. Copyright Royal Society of Chemistry, 2018.

An electronic interaction also occurs between the $\mathrm{Au}_{n}(\mathrm{SR})_{m} \mathrm{NCs}$ and a catalytic support. This phenomenon was revealed by Jin et al., by measuring the HER activity of $\mathrm{MoS}_{2}$ nanosheets (catalytic support) carrying $\mathrm{Au}_{25}(\mathrm{PET})_{18}\left(\mathrm{Au}_{25}(\mathrm{PET})_{18} / \mathrm{MoS}_{2}\right)$ [108]. In this experiment, $\mathrm{Au}_{25}(\mathrm{PET})_{18} / \mathrm{MoS}_{2}$ was prepared by mixing the $\mathrm{MoS}_{2}$ nanosheets synthesized by the hydrothermal method and $\mathrm{Au}_{25}(\mathrm{PET})_{18}$ in dichloromethane for $1 \mathrm{~h}$ and drying the obtained products under nitrogen atmosphere. High-angle annular dark-field scanning TEM (HAADF-STEM) images confirmed that $\mathrm{Au}_{25}(\mathrm{PET})_{18}$ was uniformly 
supported on $\mathrm{MoS}_{2}$ (Figure $\left.5 \mathrm{~A}\right) \cdot \mathrm{Au}_{25}(\mathrm{PET})_{18} / \mathrm{MoS}_{2}$ was then loaded on a GCE, and the HER polarization curve of $\mathrm{Au}_{25}(\mathrm{PET})_{18} / \mathrm{MoS}_{2}$ was obtained by scanning the potential in a $0.5 \mathrm{M} \mathrm{H}_{2} \mathrm{SO}_{4}$ aqueous solution using the rotating disk electrode (RDE) method (Figure 5B,D). $\mathrm{MoS}_{2}$ without $\mathrm{Au}_{25}(\mathrm{PET})_{18}$ exhibited a HER overvoltage of $0.33 \mathrm{~V}$ at a current density of $10 \mathrm{~mA} \mathrm{~cm}{ }^{-2}$, whereas $\mathrm{Au}_{25}(\mathrm{PET})_{18} / \mathrm{MoS}_{2}$ exhibited a smaller HER overvoltage of approximately $-0.28 \mathrm{~V}$ at the same current density. In addition, $\mathrm{Au}_{25}(\mathrm{PET})_{18} / \mathrm{MoS}_{2}\left(59.3 \mathrm{~mA} \mathrm{~cm}{ }^{-2}\right)$ exhibited a 1.79 times higher current density than that of $\mathrm{MoS}_{2}$ $\left(33.2 \mathrm{~mA} \mathrm{~cm}^{-2}\right)$ at an applied voltage of $-0.4 \mathrm{~V}$ vs. RHE. Thus, the HER activity of the $\mathrm{MoS}_{2}$ nanosheets was greatly improved by carrying $\mathrm{Au}_{25}(\mathrm{PET})_{18}$ (Table 1). This improvement of the HER activity was interpreted to be greatly related to the electronic interaction between $\mathrm{Au}_{25}(\mathrm{PET})_{18}$ and $\mathrm{MoS}_{2}$. In fact, X-ray photoelectron spectroscopy (XPS) analysis confirmed that the binding energy of $\mathrm{MoS}_{2}$ in the Mo $3 \mathrm{~d}$ orbit was negatively shifted by $0.4 \mathrm{eV}$ after $\mathrm{Au}_{25}(\mathrm{PET})_{18}$ was loaded (Figure $5 \mathrm{C}$ ). It was assumed that the charge transfer from $\mathrm{Au}_{25}(\mathrm{PET})_{18}$ to $\mathrm{MoS}_{2}$ occurred in $\mathrm{Au}_{25}(\mathrm{PET})_{18} / \mathrm{MoS}_{2}$, causing a high HER activity of $\mathrm{Au}_{25}(\mathrm{PET})_{18} / \mathrm{MoS}_{2}$. In this study, the HER activity of $\mathrm{MoS}_{2}$ nanosheets carrying $\mathrm{Au}_{25}(\mathrm{SePh})_{18}$ $(\mathrm{SePh}=$ phenylselenolate $)\left(\mathrm{Au}_{25}(\mathrm{SePh})_{18} / \mathrm{MoS}_{2}\right)$ was also investigated. $\mathrm{Au}_{25}(\mathrm{SePh})_{18} / \mathrm{MoS}_{2}$ was shown to also exhibit higher HER activity than $\mathrm{MoS}_{2}$ nanosheets (Table 1). However, the improvement of the activity was smaller than that when carrying $\mathrm{Au}_{25}(\mathrm{PET})_{18}$ (Figure 5D). This difference was attributed to the difference in the electron interaction and electron relay between Au cores of $\mathrm{Au}_{n} \mathrm{NCs}$ and the $\mathrm{MoS}_{2}$ nanosheet depending on the ligands. In this way, the HER activity of the $\mathrm{Au}_{n} \mathrm{NCs}$-loaded catalyst was shown to depend on the electronic interaction between the $\mathrm{Au}_{n} \mathrm{NCs}$ and the catalytic support.

A
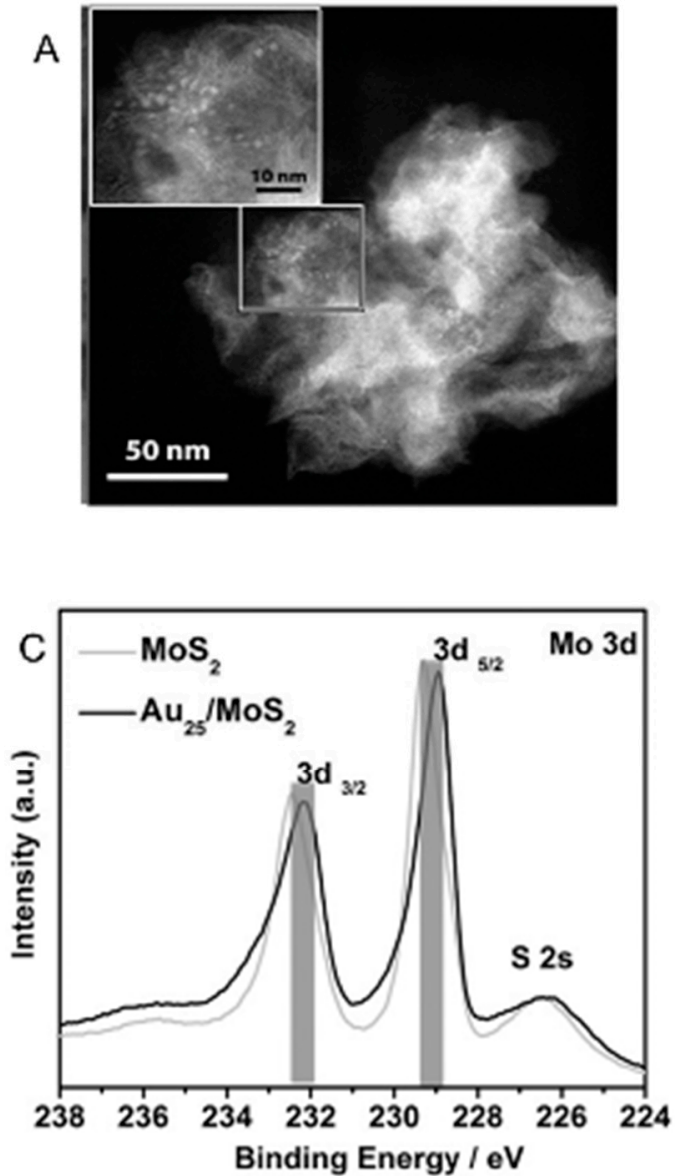
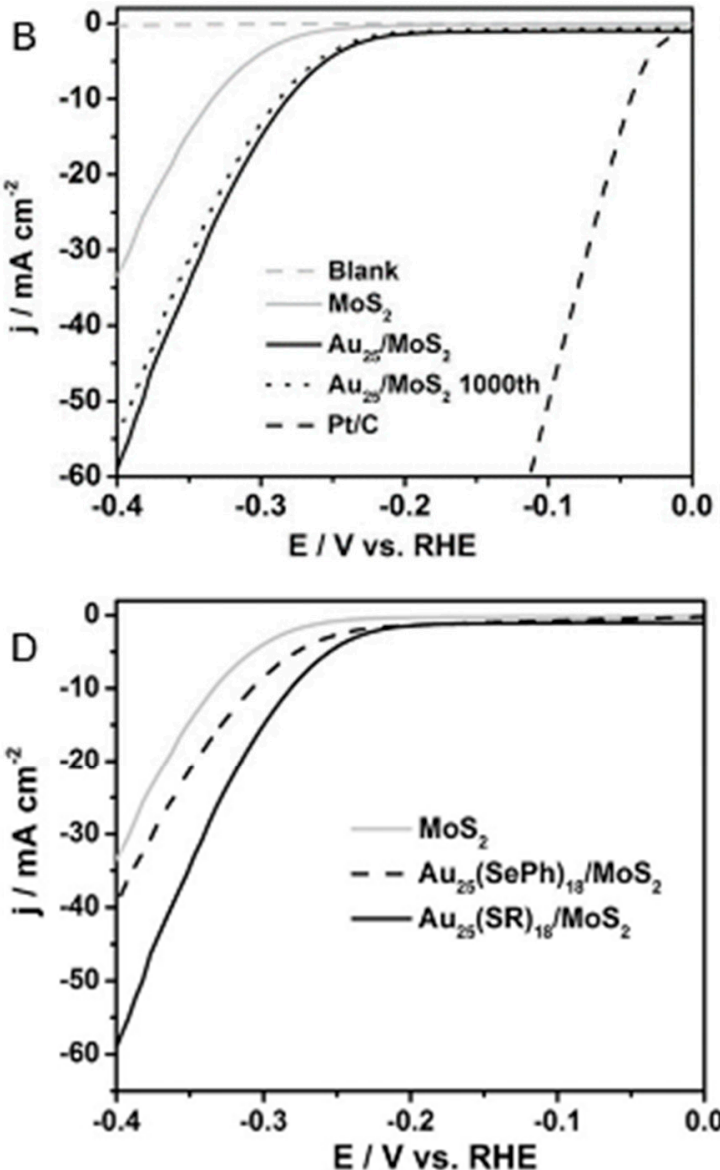

Figure 5. (A) High-angle annular dark-field scanning TEM (HAADF-STEM) images, (B) HER polarization curves, and (C) Mo 3d X-ray photoelectron spectroscopy (XPS) spectra of $\mathrm{Au}_{25}(\mathrm{PET})_{18} / \mathrm{MoS}_{2}$. (D) HER polarization curves of $\mathrm{Au}_{25}(\mathrm{SePh})_{18} / \mathrm{MoS}_{2}$. Panels $(\mathrm{A}-\mathrm{D})$ are reproduced with permission from reference [108]. Copyright Wiley-VCH, 2017. 


\subsection{Oxygen Evolution Reaction}

The OER is a multi-step four-electron reaction in which the reaction proceeds along different reaction paths depending on the binding energy between the metal and the OER intermediate $(\mathrm{O}, \mathrm{OH}$, and $\mathrm{OOH})$.

Under acidic conditions, the following reactions occur:

$$
\begin{gathered}
\mathrm{M}+\mathrm{H}_{2} \mathrm{O} \rightarrow \mathrm{M}-\mathrm{OH}+\mathrm{H}^{+}+\mathrm{e}^{-} \\
\mathrm{M}-\mathrm{OH} \rightarrow \mathrm{M}-\mathrm{O}+\mathrm{H}^{+}+\mathrm{e}^{-} \\
2(\mathrm{M}-\mathrm{O}) \rightarrow 2 \mathrm{M}+\mathrm{O}_{2} \\
\mathrm{M}-\mathrm{O}+\mathrm{H}_{2} \mathrm{O} \rightarrow \mathrm{M}-\mathrm{OOH}+\mathrm{H}^{+}+\mathrm{e}^{-} \\
\mathrm{M}-\mathrm{OOH} \rightarrow \mathrm{M}+\mathrm{O}_{2}+\mathrm{H}^{+}+\mathrm{e}^{-}
\end{gathered}
$$

However, under alkaline conditions, the following reactions occur:

$$
\begin{aligned}
\mathrm{M}+\mathrm{OH}^{-} & \rightarrow \mathrm{M}-\mathrm{OH}+\mathrm{e}^{-} \\
\mathrm{M}-\mathrm{OH}+\mathrm{OH}^{-} & \rightarrow \mathrm{M}-\mathrm{O}+\mathrm{H}_{2} \mathrm{O}+\mathrm{e}^{-} \\
2(\mathrm{M}-\mathrm{O}) & \rightarrow 2 \mathrm{M}+\mathrm{O}_{2} \\
\mathrm{M}-\mathrm{O}+\mathrm{OH}^{-} & \rightarrow \mathrm{M}-\mathrm{OOH}+\mathrm{e}^{-} \\
\mathrm{M}-\mathrm{OOH}+\mathrm{OH}^{-} & \rightarrow \mathrm{M}+\mathrm{O}_{2}+\mathrm{H}_{2} \mathrm{O}+\mathrm{e}^{-}
\end{aligned}
$$

As described above, because the reaction route of OER depends on the intermediates $(\mathrm{O}, \mathrm{OH}$, and $\mathrm{OOH}$ ) on the surface of catalyst, the OER activity of the catalyst also depends on these intermediates. Catalysts that have neither too high nor too low binding energy with oxygen species are suitable for the OER. Previous studies have demonstrated that iridium oxide and ruthenium oxide have such desirable properties. Therefore, miniaturization of these metal oxides and prediction of their physical properties by theoretical calculation have been actively performed [120-123]. However, because these precious metals are expensive and have the problem of depletion, a search for low-cost catalysts is also being conducted. Related studies have shown that cobalt (Co)-based materials (oxides, hydroxides, selenides, and phosphides) can be used as good OER catalysts. Furthermore, it has been reported that when Au NPs are composited with such Co materials, the OER performance is greatly enhanced as a result of the improved electron conductivity and preferential formation of $\mathrm{OOH}$ intermediates on the surface of the catalyst [124-126].

Jin et al., have shown that these mixing effects also occur when $\mathrm{Au}_{n} \mathrm{NCs}$ are used instead of $\mathrm{Au}$ NPs [110]. In this study, the $\mathrm{Au}_{25}(\mathrm{PET})_{18}$-loaded $\mathrm{CoSe}_{2}$ nanosheet $\left(\mathrm{Au}_{25}(\mathrm{PET})_{18} / \mathrm{CoSe}_{2}\right)$ was prepared by stirring $\mathrm{Au}_{25}(\mathrm{PET})_{18}$ and $\mathrm{CoSe}_{2}$ nanosheets in dichloromethane for $1 \mathrm{~h}$. HAADF-STEM analysis confirmed that $\mathrm{Au}_{25}(\mathrm{PET})_{18}$ was uniformly supported on the $\mathrm{CoSe}_{2}$ nanosheets (Figure $6 \mathrm{~A}, \mathrm{~B}$ ). $\mathrm{Au}_{25}(\mathrm{PET})_{18} / \mathrm{CoSe}_{2}$ was loaded on the GCE, and their OER polarization curves were obtained by scanning the applied potential $\left(5 \mathrm{mV} \mathrm{s}^{-1}\right)$ in $0.1 \mathrm{M} \mathrm{KOH}$ aqueous solution. The $\mathrm{CoSe}_{2}$ nanosheets without $\mathrm{Au}_{25}(\mathrm{PET})_{18}$ exhibited an OER overvoltage of $0.52 \mathrm{~V}$ at a current density of $10 \mathrm{~mA} \mathrm{~cm} \mathrm{~cm}^{-2}$ (Figure $1 \mathrm{~B}(\mathrm{~b})$ ), whereas $\mathrm{Au}_{25}(\mathrm{PET})_{18} / \mathrm{CoSe}_{2}$ exhibited a smaller OER overvoltage of $0.43 \mathrm{~V}$ at the same current density (Figure 6C). XPS (Figure 6E) and Raman spectroscopy (Figure 6F) analyses revealed that the electronic interaction occurred between the $\mathrm{Au}_{25}(\mathrm{PET})_{18}$ and $\mathrm{CoSe}_{2}$ nanosheet even in such a composite catalyst. Furthermore, DFT calculation revealed that the formation of the intermediate via $\mathrm{OH}^{-}$is more advantageous by $0.21 \mathrm{eV} \mathrm{mol}^{-1}$ at the interface of $\mathrm{Co}-\mathrm{Au}$ than at the surface of Co. It was thus interpreted that $\mathrm{Au}_{25}(\mathrm{PET})_{18} / \mathrm{CoSe}_{2}$ exhibited higher OER activity than the $\mathrm{CoSe}_{2}$ nanosheets because $\mathrm{Au}_{25}(\mathrm{PET})_{18} / \mathrm{CoSe}_{2}$ stabilized the generation of an $\mathrm{OOH}$ intermediate compared with only the 
$\mathrm{CoSe}_{2}$ nanosheet (Table 2). This study also revealed that the OER activity increases with the core size of $\mathrm{Au}_{n}(\mathrm{SR})_{m}$ NCs (Figure 6D).

A
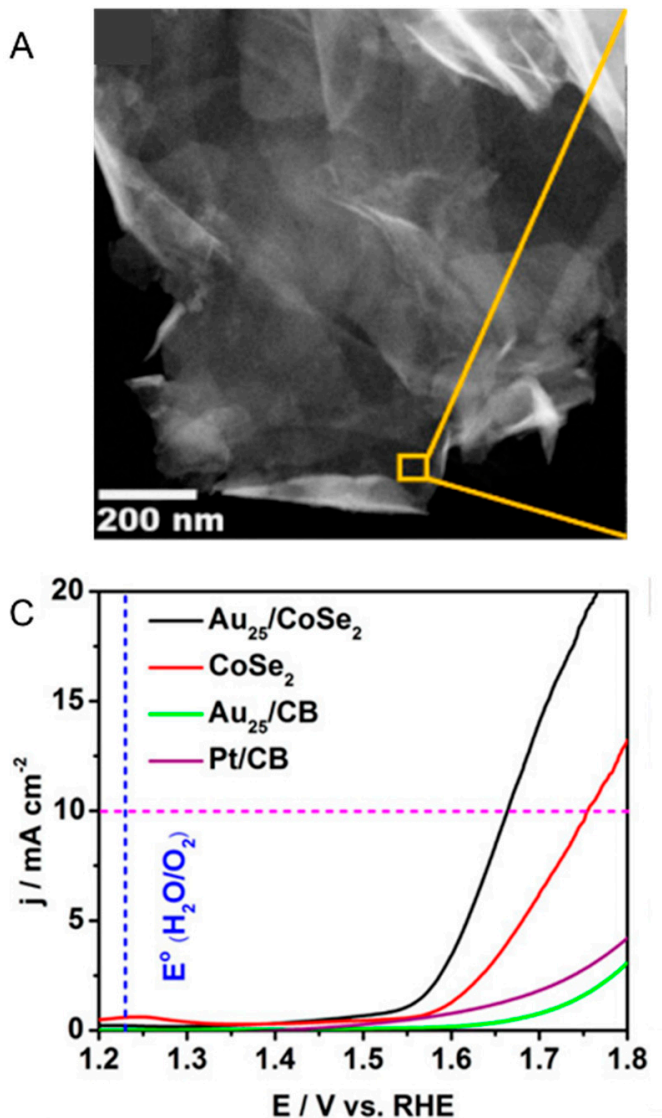

$\mathrm{E}$

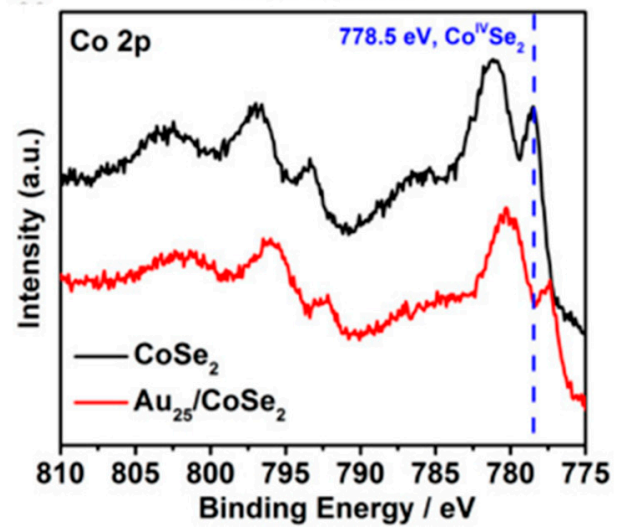

B
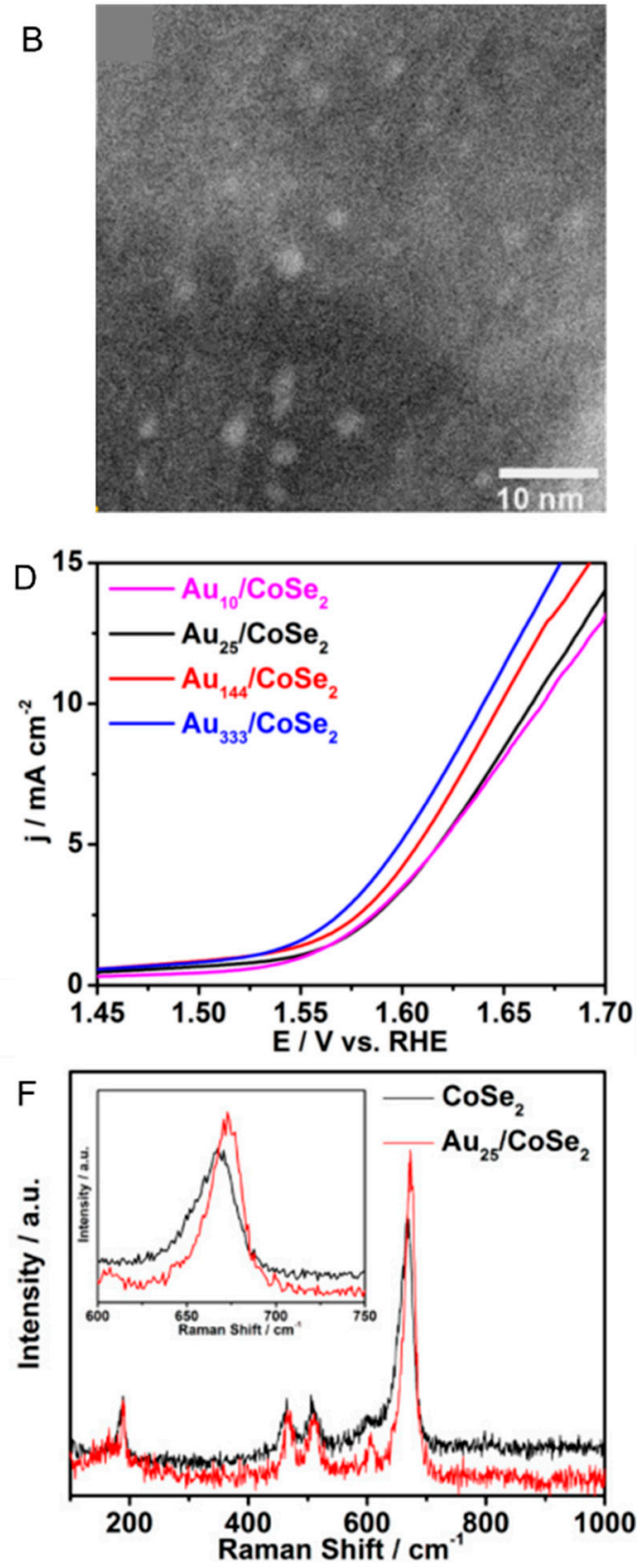

Figure 6. (A,B) HAADF-STEM images of $\mathrm{Au}_{25}(\mathrm{PET})_{18} / \mathrm{CoSe}_{2}$ composite at different magnifications. $(\mathbf{C}, \mathrm{D})$ OER polarization curves of $\mathrm{CoSe}_{2}, \quad \mathrm{Au}_{10}\left(\mathrm{SPh}^{-}{ }^{t} \mathrm{Bu}\right)_{10} / \mathrm{CoSe}_{2}, \quad \mathrm{Au}_{25}(\mathrm{PET})_{18} / \mathrm{CoSe}_{2}$, $\mathrm{Au}_{144}(\mathrm{PET})_{60} / \mathrm{CoSe}_{2}, \mathrm{Au}_{333}(\mathrm{PET})_{79} / \mathrm{CoSe}_{2}$, and $\mathrm{Pt}_{\mathrm{NP}} / \mathrm{CB}$ (CB = carbon black). (E) Co 2p XPS spectra and (F) Raman spectra of $\mathrm{CoSe}_{2}$ and $\mathrm{Au}_{25}(\mathrm{PET})_{18} / \mathrm{CoSe}_{2}$ composite. Panels (A-F) are reproduced with permission from reference [110]. Copyright American Chemical Society, 2017.

Table 2. Representative reference on OER activity of $\mathrm{Au}_{n}(\mathrm{SR})_{m} \mathrm{NCs}$.

\begin{tabular}{ccccc}
\hline Ligand & Support & Experimental Condition & Activity & Reference \\
\hline $\mathrm{PET}$ & $\mathrm{CoSe}_{2}$ & $0.1 \mathrm{M} \mathrm{KOH} \mathrm{aq}{ }^{a, b}$ & $\mathrm{Au}_{25}(\mathrm{PET})_{18} / \mathrm{CoSe}_{2}>\mathrm{CoSe}_{2}$ & {$[110]$} \\
\hline \multicolumn{5}{c}{${ }^{a}$ WE: GCE. ${ }^{b}$ WE: Containing Nafion. }
\end{tabular}




\section{Electrocatalytic Reactions in Fuel Cells}

To establish a circulating energy system that does not use fossil fuels and only produces water and a small amount of carbon dioxide as waste, it is essential to further improve the functions of fuel cells. Fuel cells can be roughly classified into those using hydrogen and those using alcohol as a fuel. In fuel cells using hydrogen as a fuel, the HOR and ORR are involved in the system. The HOR is a one-electron reaction, and generally an HER-active catalyst is also useful for the HOR. However, the ORR is a four-electron reaction, and the reaction process is complicated. In addition, the OER is a reaction under oxidizing conditions, whereas the ORR is a reaction under reducing conditions. The surface state of the catalyst and the accompanying binding to the reactants also differ greatly between the OER and ORR. Therefore, catalysts that are active for OER are not necessarily useful for the ORR. Because the ORR is rate-limiting step in a fuel cell, controlling the ORR is important for further development of fuel cells. The ORR pathways under acidic and alkaline conditions are as follows [94].

Under acidic conditions:

$$
\begin{gathered}
\mathrm{O}_{2}+4 \mathrm{H}^{+}+4 \mathrm{e}^{-} \rightarrow 2 \mathrm{H}_{2} \mathrm{O} \\
\mathrm{O}_{2}+2 \mathrm{H}^{+}+2 \mathrm{e}^{-} \rightarrow \mathrm{H}_{2} \mathrm{O}_{2} \\
\mathrm{H}_{2} \mathrm{O}_{2}+2 \mathrm{H}^{+}+2 \mathrm{e}^{-} \rightarrow 2 \mathrm{H}_{2} \mathrm{O}
\end{gathered}
$$

Under alkaline conditions:

$$
\begin{gathered}
\mathrm{O}_{2}+2 \mathrm{H}_{2} \mathrm{O}+4 \mathrm{e}^{-} \rightarrow 4 \mathrm{OH}^{-} \\
\mathrm{O}_{2}+\mathrm{H}_{2} \mathrm{O}+2 \mathrm{e}^{-} \rightarrow \mathrm{OOH}^{-}+\mathrm{OH}^{-} \\
\mathrm{OOH}^{-}+\mathrm{H}_{2} \mathrm{O}+2 \mathrm{e}^{-} \rightarrow 3 \mathrm{OH}^{-}
\end{gathered}
$$

Equations (17) and (20) are four-electron reactions, and Equations (18), (19), (21), and (22) are two-electron reactions. For both sets of reactions, the reactions start with the breaking of the $\mathrm{O}-\mathrm{O}$ bond. The theoretical redox potential is $1.23 \mathrm{~V}$ vs. SHE in the direct four-electron path and $0.68 \mathrm{~V}$ vs. SHE in the indirect two-electron path. Therefore, a higher energy conversion efficiency can be achieved using the direct four-electron path, and this reaction path is thus more desirable for fuel cells [81]. Although Pt is a useful catalyst for such a reaction pathway, it is expected to be replaced with another metal element because of the high cost of $\mathrm{Pt}$ and the resource depletion issue. In addition, synthesis methods of $\mathrm{Pt}_{n} \mathrm{NCs}$ in ambient atmosphere with atomic precision are limited, and therefore, it is difficult to study the ORR mechanism using $\mathrm{Pt}_{n} \mathrm{NCs}$ as model catalysts. However, for $\mathrm{Au}_{n} \mathrm{NCs}$, there are many examples of synthesis with atomic precision, and these catalysts are stable in ambient atmosphere. In addition, theoretical calculations $[127,128]$ and experimental results $[65,129]$ have predicted that $\mathrm{O}_{2}$ molecules can be highly activated on the surface of $\mathrm{Au}_{n} \mathrm{NCs}$. For these reasons, several studies have also been performed on the application of $\mathrm{Au}_{n} \mathrm{NCs}$ as ORR catalysts.

In 2009, Chen et al., evaluated the ORR catalytic activity of $\mathrm{Au}_{11}\left(\mathrm{PPh}_{3}\right)_{8} \mathrm{Cl}_{3}, \mathrm{Au}_{25}(\mathrm{PET})_{18}$, $\mathrm{Au}_{55}\left(\mathrm{PPh}_{3}\right)_{12} \mathrm{Cl}_{6}$, and $\mathrm{Au}_{140}\left(\mathrm{SC}_{6} \mathrm{H}_{13}\right)_{53}(\mathrm{Cl}=$ chlorine $)$ [111]. In this experiment, after a series of $\mathrm{Au}_{n}$ NCs were loaded on the GCE, the ORR activity was measured by scanning the potential using the RDE method in a $0.1 \mathrm{M} \mathrm{KOH}$ aqueous solution filled with $\mathrm{O}_{2}$. When $\mathrm{Au}_{11}\left(\mathrm{PPh}_{3}\right)_{8} \mathrm{Cl}_{3}$ was used as the $\mathrm{Au}_{n} \mathrm{NCs}$, the onset potential of the ORR (Figure $1 \mathrm{~B}(\mathrm{c})$ ) was about $-0.08 \mathrm{~V}$, and the peak current density was $2.4 \mathrm{~mA} \mathrm{~cm}{ }^{-2}$ (Figure 7A). However, when $\mathrm{Au}_{140}\left(\mathrm{SC}_{6} \mathrm{H}_{13}\right)_{53}$ was used as the $\mathrm{Au}_{n} \mathrm{NCs}$, the onset potential shifted to the more cathodic $-0.22 \mathrm{~V}$ and the reduction peak current decreased to less than $1.0 \mathrm{~mA} \mathrm{~cm}^{-2}$. These results and those for the other two $\mathrm{Au}_{n} \mathrm{NCs}$ indicated that the ORR activity increased with decreasing $\mathrm{Au}$ core size $\left(\mathrm{Au}_{11}\left(\mathrm{PPh}_{3}\right)_{8} \mathrm{Cl}_{3}>\mathrm{Au}_{25}(\mathrm{PET})_{18}>\mathrm{Au}_{55}\left(\mathrm{PPh}_{3}\right)_{12} \mathrm{Cl}_{6}\right.$ $\left.>\mathrm{Au}_{140}\left(\mathrm{SC}_{6} \mathrm{H}_{13}\right)_{53}\right)$ (Figure $7 \mathrm{~A}, \mathrm{~B}$ and Table 3). From estimation of the number of electrons for the ORR from a Koutecky-Levich plot [85], it was observed that the relatively small size of $\mathrm{Au}_{n} \mathrm{NCs}$ $\left(\mathrm{Au}_{11}\left(\mathrm{PPh}_{3}\right)_{8} \mathrm{Cl}_{3}, \mathrm{Au}_{25}(\mathrm{PET})_{18}\right.$, and $\left.\mathrm{Au}_{55}\left(\mathrm{PPh}_{3}\right)_{12} \mathrm{Cl}_{6}\right)$ resulted in the occurrence of the four-electron reaction, whereas $\mathrm{Au}_{140}\left(\mathrm{SC}_{6} \mathrm{H}_{13}\right)_{53}$ tended to follow the two-electron reaction pathway (Figure $7 \mathrm{C}, \mathrm{D}$ ). Later, these researchers also synthesized a series of $\mathrm{Au}_{n}(\mathrm{SR})_{m} \mathrm{NCs}\left(\mathrm{Au}_{25}(\mathrm{PET})_{18}, \mathrm{Au}_{38}(\mathrm{PET})_{24}\right.$, and 
$\left.\mathrm{Au}_{144}(\mathrm{PET})_{60}\right)$ with PET ligands and measured their ORR activities. The results revealed that a smaller core size was associated with higher ORR activity: $\mathrm{Au}_{25}(\mathrm{PET})_{18}>\mathrm{Au}_{38}(\mathrm{PET})_{24}>\mathrm{Au}_{144}(\mathrm{PET})_{60}$ (Table 3) [112]. As the core size decreased, the ratio of low-coordinated surface atoms increased and the d-band center of the Fermi level changed. It was interpreted that smaller $\mathrm{Au}_{n}(\mathrm{SR})_{m} \mathrm{NCs}$ exhibited higher ORR activity because the promotion of oxygen adsorption on the gold core surface was accelerated by miniaturization of the metal core.
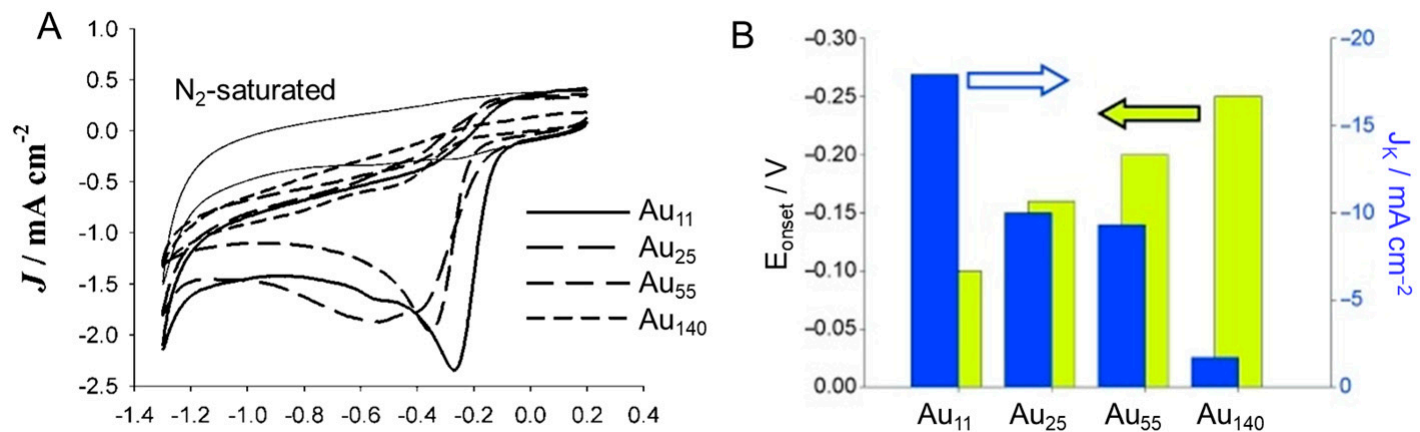

E / V vs. Ag/AgCl
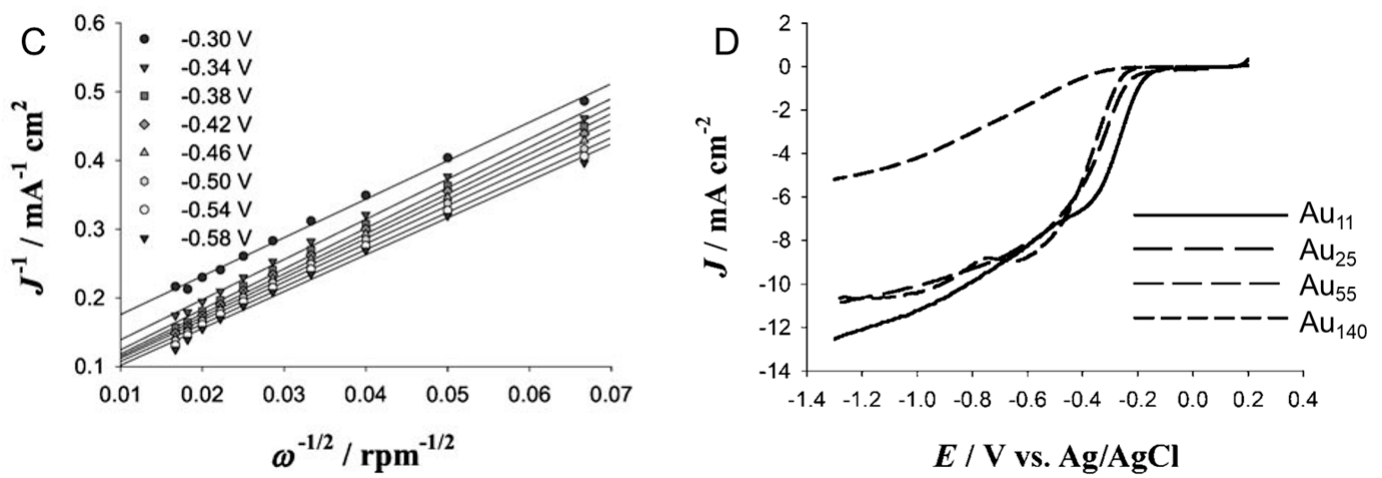

Figure 7. (A) Cyclic voltammograms of $\mathrm{Au}_{n}(\mathrm{SR})_{m} / \mathrm{GCE}\left(n=11,25,55\right.$, and 140) saturated with $\mathrm{O}_{2}$ and $\mathrm{Au}_{11}\left(\mathrm{PPh}_{3}\right)_{8} \mathrm{Cl}_{3} / \mathrm{GCE}$ saturated with $\mathrm{N}_{2}$ (thin solid curve). (B) Current density and overpotential of ORR activity with each size of $\mathrm{Au}_{n}$ NCs. (C) Koutecky-Levich plots at different applied potentials of a GCE modified with $\mathrm{Au}_{11}\left(\mathrm{PPh}_{3}\right)_{8} \mathrm{Cl}_{3}$. (D) Rotating-disk voltammograms (rotation rate: $3600 \mathrm{rpm}$ ) of various $\mathrm{Au}_{n}(\mathrm{SR})_{m} / \mathrm{GCE}(n=11,25,55$, and 140). Panels (A-D) are reproduced with permission from reference [111]. Copyright Wiley-VCH, 2009.

Table 3. Representative references on ORR activity of $\mathrm{Au}_{n} \mathrm{NCs}$.

\begin{tabular}{|c|c|c|c|c|}
\hline Ligand & Support & Experimental Condition & Activity & Reference \\
\hline PET & & & & \\
\hline $\begin{array}{l}\mathrm{SC}_{6} \mathrm{H}_{13} \\
\mathrm{Cl}\end{array}$ & - & $0.1 \mathrm{M} \mathrm{KOH} \mathrm{aq}^{a}$ & $\begin{array}{c}\mathrm{Au}_{11}\left(\mathrm{PPh}_{3}\right)_{8} \mathrm{Cl}_{3}>\mathrm{Au}_{25}(\mathrm{PET})_{18}>\mathrm{Au}_{55}\left(\mathrm{PPh}_{3}\right)_{12} \mathrm{Cl}_{6}> \\
\mathrm{Au}_{140}\left(\mathrm{SC}_{6} \mathrm{H}_{13}\right)_{53}\end{array}$ & [101] \\
\hline $\mathrm{PPh}_{3}$ & & & & \\
\hline PET & Reduced graphene oxide & $0.1 \mathrm{M} \mathrm{KOH} \mathrm{aq}{ }^{a, b}$ & $\mathrm{Au}_{25}(\mathrm{PET})_{18}>\mathrm{Au}_{38}(\mathrm{PET})_{24}>\mathrm{Au}_{144}(\mathrm{PET})_{60}$ & [112] \\
\hline TBBT & SWNTs & $0.1 \mathrm{M} \mathrm{KOH} \mathrm{aq}{ }^{a, b}$ & $\mathrm{Au}_{36}(\mathrm{TBBT})_{24}>\mathrm{Au}_{133}(\mathrm{TBBT})_{52}>\mathrm{Au}_{279}(\mathrm{TBBT})_{84}>\mathrm{Au}_{28}(\mathrm{TBBT})_{20}$ & [113] \\
\hline $\mathrm{S}-{ }^{t} \mathrm{Bu}$ & SWNTs & $0.1 \mathrm{M} \mathrm{KOH} \mathrm{aq}{ }^{a, b}$ & $\mathrm{Au}_{65}\left(\mathrm{~S}-{ }^{t} \mathrm{Bu}\right)_{29}>\mathrm{Au}_{46}\left(\mathrm{~S}-{ }^{t} \mathrm{Bu}\right)_{24}>\mathrm{Au}_{30}\left(\mathrm{~S}-{ }^{t} \mathrm{Bu}\right)_{18}>\mathrm{Au}_{23}\left(\mathrm{~S}-{ }^{t} \mathrm{Bu}\right)_{16}$ & [114] \\
\hline $\mathrm{SC}_{12} \mathrm{H}_{25}$ & - & $0.1 \mathrm{M} \mathrm{KOH} \mathrm{aq}{ }^{a, b}$ & {$\left[\mathrm{Au}_{25}\left(\mathrm{SC}_{12} \mathrm{H}_{25}\right)_{18}\right]^{-}>\left[\mathrm{Au}_{25}\left(\mathrm{SC}_{12} \mathrm{H}_{25}\right)_{18}\right]^{0}>\left[\mathrm{Au}_{25}\left(\mathrm{SC}_{12} \mathrm{H}_{25}\right)_{18}\right]^{+c}$} & [115] \\
\hline
\end{tabular}

${ }^{a}$ WE: GCE. ${ }^{b}$ WE; Containing Nafion. ${ }^{c}$ Tow-electron reduction.

On the other hand, Dass et al., studied the dependence of the ORR activity on the core size using $\mathrm{Au}_{n}$ NCs protected by 4-tert-butylbenzenethiolate (TBBT), whose structure differs significantly from that of PET [113]. In this experiment, single-walled carbon nanotubes (SWNTs) carrying $\mathrm{Au}_{n}(\mathrm{TBBT})_{m}$ NCs $\left(n=28,36,133\right.$, and 279; Figure 8A; $\mathrm{Au}_{n}(\mathrm{TBBT})_{m}$ NCs/SWNTs) were loaded onto the GCE. The ORR actives were measured by scanning the potential using the RDE method in a $0.1 \mathrm{M} \mathrm{KOH}$ aqueous solution filled with $\mathrm{O}_{2}$ (Figure 8B). The overvoltage of the ORR was smaller in the order of $\mathrm{Au}_{36}(\mathrm{TBBT})_{24}>\mathrm{Au}_{133}(\mathrm{TBBT})_{52}>\mathrm{Au}_{279}(\mathrm{TBBT})_{84}>\mathrm{Au}_{28}(\mathrm{TBBT})_{20}$. However, the selectivity of the four-electron reduction reaction was superior in the order of $\mathrm{Au}_{36}(\mathrm{TBBT})_{24} \approx \mathrm{Au}_{133}(\mathrm{TBBT})_{52}>$ 
$\mathrm{Au}_{279}(\mathrm{TBBT})_{84}>\mathrm{Au}_{28}(\mathrm{TBBT})_{20}$ [113] (Figure 8C). Notably, this trend was similar to that of the size dependence of the stability of $\mathrm{Au}_{n}(\mathrm{TBBT})_{m}$ NCs itself. The same group performed similar studies using tert-butylthiolate ( $\mathrm{S}-{ }^{t} \mathrm{Bu}$ ) instead of TBBT as a ligand [114]. S- ${ }^{t} \mathrm{Bu}$ has a bulky framework and when this ligand is used in the synthesis of $\mathrm{Au}_{n}(\mathrm{SR})_{m} \mathrm{NCs}$, the ratio of the metal atom and the ligand in the generated $\mathrm{Au}_{n}(\mathrm{SR})_{m}$ NCs is different from that in $\mathrm{Au}_{n}(\mathrm{SR})_{m}$ NCs synthesized using another ligand. Such $\mathrm{Au}_{n}\left(\mathrm{~S}-{ }^{t} \mathrm{Bu}\right)_{m} \mathrm{NCs}$ exhibit a unique size dependency for ORR activity $\left(\mathrm{Au}_{65}\left(\mathrm{~S}-{ }^{t} \mathrm{Bu}\right)_{29}>\right.$ $\left.\mathrm{Au}_{46}\left(\mathrm{~S}-{ }^{t} \mathrm{Bu}\right)_{24}>\mathrm{Au}_{30}\left(\mathrm{~S}-{ }^{t} \mathrm{Bu}\right)_{18}>\mathrm{Au}_{23}\left(\mathrm{~S}-{ }^{t} \mathrm{Bu}\right)_{16}\right)[114]$.

A

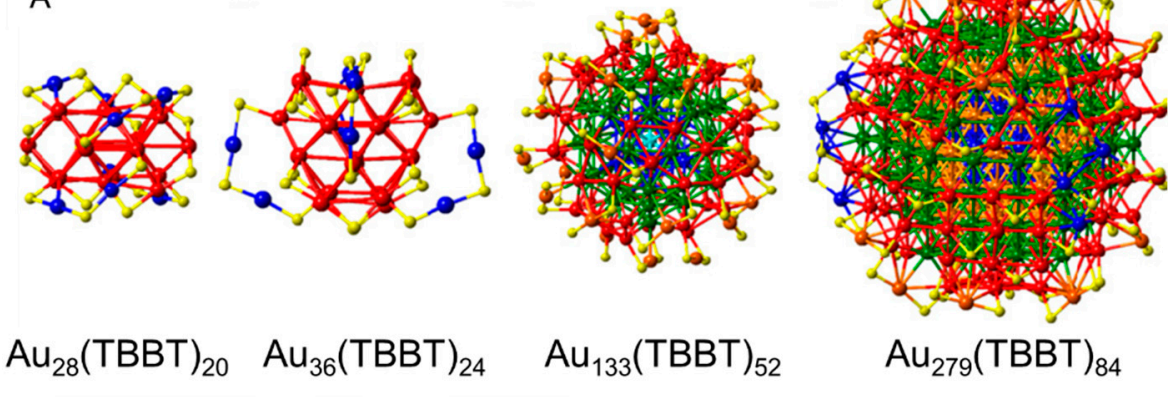
E/V vs RHE
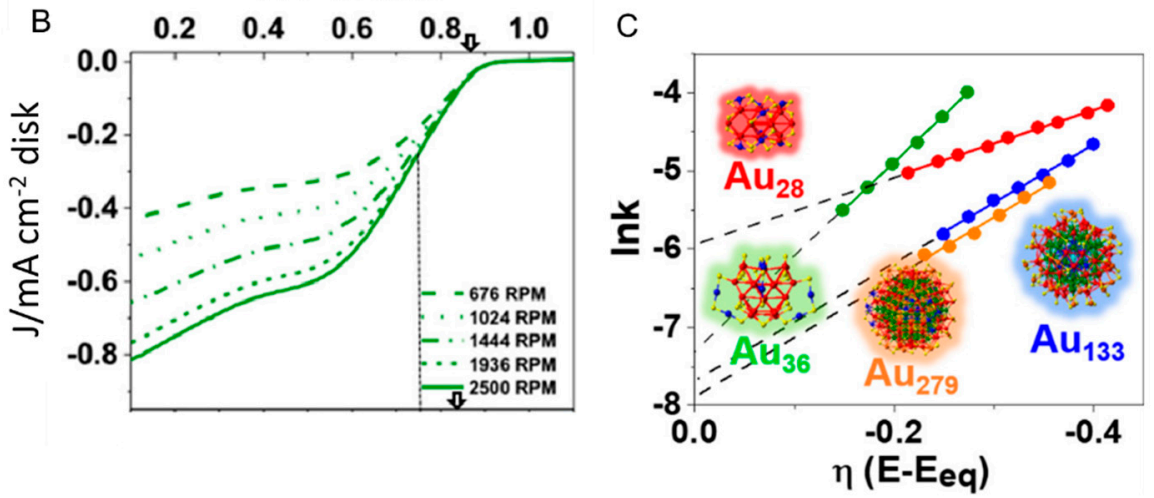

Figure 8. (A) X-ray crystal structures of $\mathrm{Au}_{n}(\mathrm{TBBT})_{m} \mathrm{NCs}(n=28,36,133$, and 279). (B) Rotating-disk voltammograms recorded for the ORR activity of $\mathrm{Au}_{36}(\mathrm{TBBT})_{24} / \mathrm{GCE}$ at different rotation rates. (C) Reaction rate constant $\ln (k)$ vs. overpotential E plots with each size of $\mathrm{Au}_{n}(\mathrm{TBBT})_{m}(n=28,36,133$, and 279). Panels (A-C) are reproduced with permission from reference [113]. Copyright American Chemical Society, 2018.

In addition to these effects of core sizes and ligands, the ORR activity also depended on the charge state of $\mathrm{Au}_{n}(\mathrm{SR})_{m} \mathrm{NCs}$. Chen et al., carried $\left[\mathrm{Au}_{25}\left(\mathrm{SC}_{12} \mathrm{H}_{25}\right)_{18}\right]^{-},\left[\mathrm{Au}_{25}\left(\mathrm{SC}_{12} \mathrm{H}_{25}\right)_{18}\right]^{0}$, and $\left[\mathrm{Au}_{25}\left(\mathrm{SC}_{12} \mathrm{H}_{25}\right)_{18}\right]^{+}\left(\mathrm{SC}_{12} \mathrm{H}_{25}=1\right.$-dodecanethiolate $)$ on the $\mathrm{GCE}$, and their ORR activities were evaluated by scanning the potential in a $0.1 \mathrm{M} \mathrm{KOH}$ aqueous solution using a rotating ring-disk electrode (RRDE) filled with $\mathrm{O}_{2}$ [115]. In addition, the generation of $\mathrm{H}_{2} \mathrm{O}_{2}$ was evaluated from the RRDE current at a fixed ring potential $\left(0.5 \mathrm{~V}\right.$ vs. saturated calomel electrode (SCE)). When $\left[\mathrm{Au}_{25}\left(\mathrm{SC}_{12} \mathrm{H}_{25}\right)_{18}\right]^{-}$, [ $\left.\mathrm{Au}_{25}\left(\mathrm{SC}_{12} \mathrm{H}_{25}\right)_{18}\right]^{0}$, and $\left[\mathrm{Au}_{25}\left(\mathrm{SC}_{12} \mathrm{H}_{25}\right)_{18}\right]^{+}$were used, the efficiencies of $\mathrm{H}_{2} \mathrm{O}_{2}$ were $86 \%, 82 \%$, and $72 \%$, respectively. In addition, the number of electrons for the ORR was estimated to be $2.28\left(\left[\mathrm{Au}_{25}\left(\mathrm{SC}_{12} \mathrm{H}_{25}\right)_{18}\right]^{-}\right), 2.35\left(\left[\mathrm{Au}_{25}\left(\mathrm{SC}_{12} \mathrm{H}_{25}\right)_{18}\right]^{0}\right)$, and $2.56\left(\left[\mathrm{Au}_{25}\left(\mathrm{SC}_{12} \mathrm{H}_{25}\right)_{18}\right]^{+}\right.$; Figure 9A-C). For $\left[\mathrm{Au}_{25}\left(\mathrm{SC}_{12} \mathrm{H}_{25}\right)_{18}\right]^{-}$, which showed the highest production rate of $\mathrm{H}_{2} \mathrm{O}_{2}$, the activity decreased only $9 \%$ even after 1000 cycles (Figure 9D). These results indicate that $\left[\mathrm{Au}_{25}\left(\mathrm{SC}_{12} \mathrm{H}_{25}\right)_{18}\right]^{-}$has high $\mathrm{H}_{2} \mathrm{O}_{2}$ generating ability (Table 3) [115]. Since $\mathrm{H}_{2} \mathrm{O}_{2}$ is a useful raw material for chemical products, the development of their highly selective production reactions is important. Jin et al., also studied the dependence of the ORR activity on the charge state of $\mathrm{Au}_{n}(\mathrm{SR})_{m} \mathrm{NCs}$ using $\left[\mathrm{Au}_{25}(\mathrm{PET})_{18}\right]^{-}$, $\left[\mathrm{Au}_{25}(\mathrm{PET})_{18}\right]^{0}$, and $\left[\mathrm{Au}_{25}(\mathrm{PET})_{18}\right]^{+}$. They reported that too strong of an $\mathrm{OH}^{-}$adsorbing ability of 
$\left[\mathrm{Au}_{25}(\mathrm{PET})_{18}\right]^{+}$reduces the ORR activity [77]. Thus, it has been clarified that the charge state of $\mathrm{Au}_{n}(\mathrm{SR})_{m} \mathrm{NCs}$ also has a significant effect on the ORR activity of $\mathrm{Au}_{n}(\mathrm{SR})_{m} \mathrm{NCs}$.
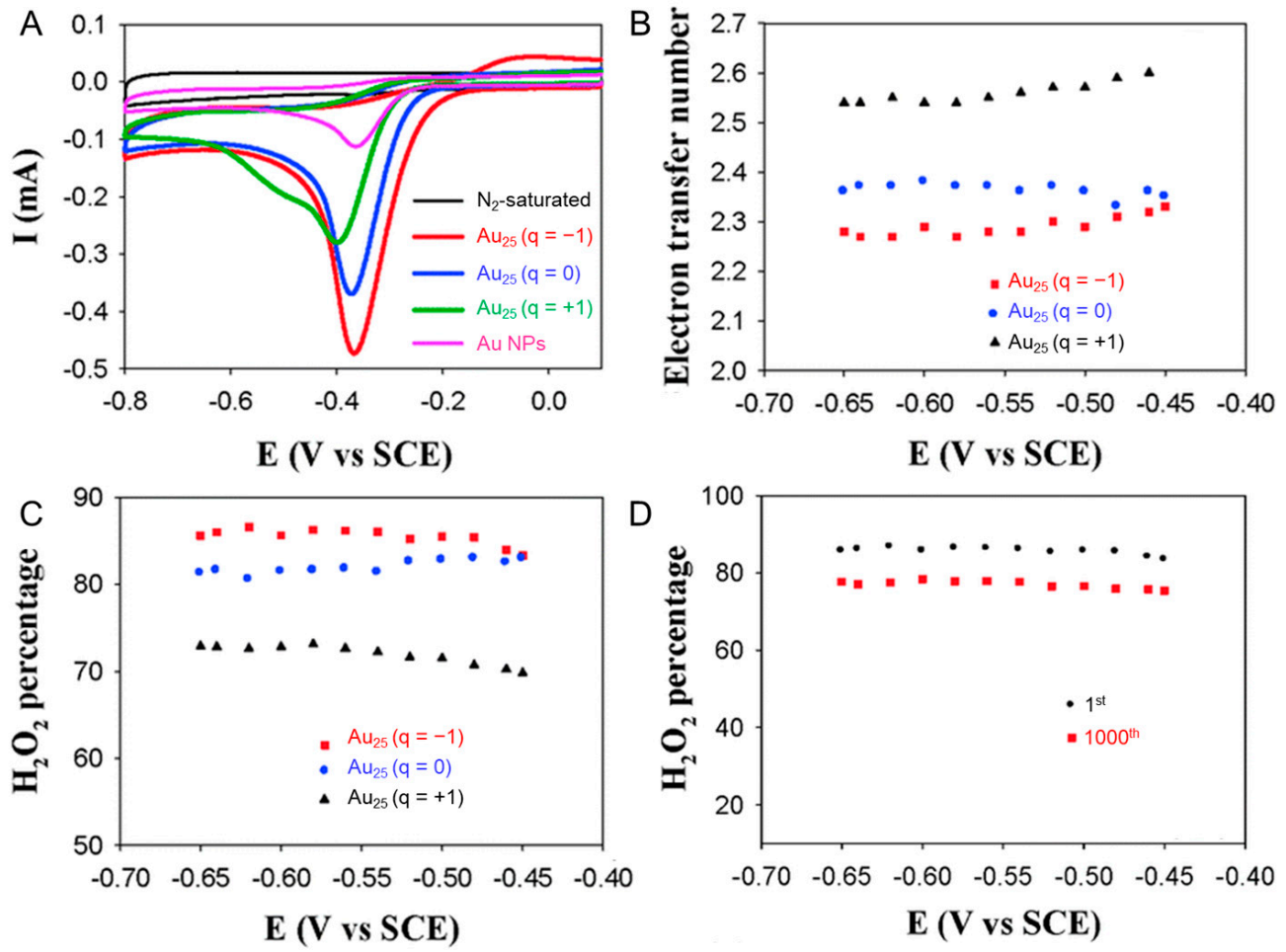

Figure 9. (A) Cyclic voltammograms, (B) electron transfer number ( $n$ ), and (C) percentage of $\mathrm{H}_{2} \mathrm{O}_{2}$ of the ORR on $\mathrm{Au}_{25}\left(\mathrm{SC}_{12} \mathrm{H}_{25}\right)_{18}$ with different charge states $\left(\left[\mathrm{Au}_{25}\left(\mathrm{SC}_{12} \mathrm{H}_{25}\right)_{18}\right]^{-}\right.$, $\left[\mathrm{Au}_{25}\left(\mathrm{SC}_{12} \mathrm{H}_{25}\right)_{18}\right]^{0}$, and $\left.\left[\mathrm{Au}_{25}\left(\mathrm{SC}_{12} \mathrm{H}_{25}\right)_{18}\right]^{+}\right)$in $0.1 \mathrm{M} \mathrm{KOH}$ aq saturated with $\mathrm{O}_{2}$. (D) Accelerated durability tests of $\left[\mathrm{Au}_{25}\left(\mathrm{SC}_{12} \mathrm{H}_{25}\right)_{18}\right]^{-}$performed for 1000 cycles. Panels (A-D) are reproduced with permission from reference [115]. Copyright Royal Society of Chemistry, 2014.

\section{Conclusions}

A system for the generation of a fuel such as hydrogen or methanol using natural energy (e.g., solar cells or photocatalytic water splitting) and the production of electricity by fuel cells using these fuels would be one of the ultimate energy conversion systems for our society. To realize such a system, high activation of the HER, OER, HOR, and ORR is indispensable. Recently, $\mathrm{Au}_{n} \mathrm{NC}$ s have attracted considerable attention as model catalysts for these reactions. In this review, recent works on these materials were summarized. The overall characteristics of the HER, OER, and ORR can be summarized as follows.

1) Since the core size, doping metal, ligand structure, and charge state affect the electronic and geometrical structures of $\mathrm{Au}_{n} \mathrm{NCs}$, these parameters also have a great effect on the catalytic activity of $\mathrm{Au}_{n} \mathrm{NCs}$.

2) Although these three reactions proceed via different mechanisms, reducing the core size of $\mathrm{Au}_{n}$ NCs and improving the ligand conductivity tend to improve the activities.

3) When $\mathrm{Au}_{n} \mathrm{NCs}$ are carried on a conventional catalytic support, their electronic structure changes and thus their catalytic activity also changes. Therefore, $\mathrm{Au}_{n} \mathrm{NCs}$ are also useful for improving the catalytic activity of conventional catalytic materials.

\section{Perspectives}

Until recently, the materials with relatively high activity for all of HER, OER, and ORR are considered to be limited to $\mathrm{Ir}, \mathrm{Rh}, \mathrm{Ru}$, and $\mathrm{Pt}[84,85]$. However, the recent studies demonstrated that 
these properties could also be caused in Au by the discretization of the band structure (e.g., shift of d-band center $[107,111])$. For $\mathrm{Au}_{n} \mathrm{NCs}$, it is possible to precisely control the electronic/geometrical structures and thereby to elucidate the correlation between catalytic activity and electronic/geometrical structure. In addition, the use of fine $\mathrm{Au}_{n} \mathrm{NCs}$ as a catalyst is effective in reducing the consumption of expensive noble metals. It is expected that the studies on the catalytic activities of $\mathrm{Au}_{n} \mathrm{NCs}$ lead to solve the mechanism in catalytic reactions on the metal surface and create the amazing catalysts we have never seen.

However, to create such HER, OER, and ORR catalysts using $\mathrm{Au}_{n} \mathrm{NCs}$ and their alloy NCs, further studies are required. Previous studies have shown that doping with Group 10 elements (Pt and $\mathrm{Pd}$ ) induces high activation. Thus, a method for increasing the doping concentration of these elements is expected to be developed in the future. In addition, regarding the HER and OER, in spite of decomposing water, most studies thus far have used hydrophobic ligands that are not compatible with water. This may be related to the fact that the synthesis of hydrophobic $\mathrm{Au}_{n} \mathrm{NCs}$ is easier than that of hydrophilic $\mathrm{Au}_{n}$ NCs. In particular, it is difficult to selectively synthesize a group-10-element-doped cluster using a hydrophilic ligand using the conventional synthesis method. However, as shown in this review, it is more appropriate to use hydrophilic $A u_{n}$ NCs as HER and OER catalysts. Therefore, in the future, additional research on hydrophilic $\mathrm{Au}_{n} \mathrm{NCs}$ is expected to increase the types of ligands and core sizes of hydrophilic $\mathrm{Au}_{n}$ NCs. Such studies are expected to lead to the creation of highly active HER, OER, and ORR catalysts and eventually to the development of design guidelines for establishing ultimate energy conversion systems.

Author Contributions: T.K. and Y.N. developed the idea for this review article and wrote the paper. All authors have read and agreed to the published version of the manuscript.

Funding: This work was supported by the Japan Society for the Promotion of Science (JSPS) KAKENHI (grant number JP18K14074 and JP18H01953), Scientific Research on Innovative Areas "Coordination Asymmetry" (grant number 17H05385) and Scientific Research on Innovative Areas "Innovations for Light-Energy Conversion" (grant number 18H05178).

Conflicts of Interest: There are no conflicts to declare.

\section{References}

1. Brust, M.; Walker, M.; Bethell, D.; Schiffrin, D.J.; Whyman, R. Synthesis of Thiol-Derivatised Gold Nanoparticles in a Two-Phase Liquid-Liquid System. J. Chem. Soc. Chem. Commun. 1994, 801-802. [CrossRef]

2. Jin, R.; Zeng, C.; Zhou, M.; Chen, Y. Atomically Precise Colloidal Metal Nanoclusters and Nanoparticles: Fundamentals and Opportunities. Chem. Rev. 2016, 116, 10346-10413. [CrossRef] [PubMed]

3. Kurashige, W.; Niihori, Y.; Sharma, S.; Negishi, Y. Precise Synthesis, Functionalization and Application of Thiolate-Protected Gold Clusters. Coord. Chem. Rev. 2016, 320, 238-250. [CrossRef]

4. Hossain, S.; Niihori, Y.; Nair, L.V.; Kumar, B.; Kurashige, W.; Negishi, Y. Alloy Clusters: Precise Synthesis and Mixing Effects. Acc. Chem. Res. 2018, 51, 3114-3124. [CrossRef] [PubMed]

5. Gan, Z.; Xia, N.; Wu, Z. Discovery, Mechanism; Application of Antigalvanic Reaction. Acc. Chem. Res. 2018, 51, 2774-2783. [CrossRef] [PubMed]

6. Chakraborty, I.; Pradeep, T. Atomically Precise Clusters of Noble Metals: Emerging Link between Atoms and Nanoparticles. Chem. Rev. 2017, 117, 8208-8271. [CrossRef]

7. Yao, Q.; Chen, T.; Yuan, X.; Xie, J. Toward Total Synthesis of Thiolate-Protected Metal Nanoclusters. Acc. Chem. Res. 2018, 51, 1338-1348. [CrossRef]

8. Qian, H.; Zhu, M.; Wu, Z.; Jin, R. Quantum Sized Gold Nanoclusters with Atomic Precision. Acc. Chem. Res. 2012, 45, 1470-1479. [CrossRef]

9. Whetten, R.L.; Weissker, H.-C.; Pelayo, J.J.; Mullins, S.M.; López-Lozano, X.; Garzón, I.L. Chiral-Icosahedral (I) Symmetry in Ubiquitous Metallic Cluster Compounds (145A,60X): Structure and Bonding Principles. Acc. Chem. Res. 2019, 52, 34-43. [CrossRef]

10. Aikens, C.M. Electronic and Geometric Structure, Optical Properties, and Excited State Behavior in Atomically Precise Thiolate-Stabilized Noble Metal Nanoclusters. Acc. Chem. Res. 2018, 51, 3065-3073. [CrossRef] 
11. Nieto-Ortega, B.; Bürgi, T. Vibrational Properties of Thiolate-Protected Gold Nanoclusters. Acc. Chem. Res. 2018, 51, 2811-2819. [CrossRef] [PubMed]

12. Agrachev, M.; Ruzzi, M.; Venzo, A.; Maran, F. Nuclear and Electron Magnetic Resonance Spectroscopies of Atomically Precise Gold Nanoclusters. Acc. Chem. Res. 2019, 52, 44-52. [CrossRef] [PubMed]

13. Pei, Y.; Wang, P.; Ma, Z.; Xiong, L. Growth-Rule-Guided Structural Exploration of Thiolate-Protected Gold Nanoclusters. Acc. Chem. Res. 2019, 52, 23-33. [CrossRef] [PubMed]

14. Ghosh, A.; Mohammed, O.F.; Bakr, O.M. Atomic-Level Doping of Metal Clusters. Acc. Chem. Res. 2018, 51, 3094-3103. [CrossRef]

15. Bigioni, T.P.; Whetten, R.L.; Dag, Ö. Near-Infrared Luminescence from Small Gold Nanocrystals. J. Phys. Chem. B 2000, 104, 6983-6986. [CrossRef]

16. Yan, J.; Teo, B.K.; Zheng, N. Surface Chemistry of Atomically Precise Coinage-Metal Nanoclusters: From Structural Control to Surface Reactivity and Catalysis. Acc. Chem. Res. 2018, 51, 3084-3093. [CrossRef]

17. Sakthivel, N.A.; Dass, A. Aromatic Thiolate-Protected Series of Gold Nanomolecules and a Contrary Structural Trend in Size Evolution. Acc. Chem. Res. 2018, 51, 1774-1783. [CrossRef]

18. Tang, Q.; Hu, G.; Fung, V.; Jiang, D.-E. Insights into Interfaces, Stability, Electronic Properties, and Catalytic Activities of Atomically Precise Metal Nanoclusters from First Principles. Acc. Chem. Res. 2018, 51, 2793-2802. [CrossRef]

19. Negishi, Y.; Nobusada, K.; Tsukuda, T. Glutathione-Protected Gold Clusters Revisited: Bridging the Gap between Gold(I)-Thiolate Complexes and Thiolate-Protected Gold Nanocrystals. J. Am. Chem. Soc. 2005, 127, 5261-5270. [CrossRef]

20. Jadzinsky, P.D.; Calero, G.; Ackerson, C.J.; Bushnell, D.A.; Kornberg, R.D. Structure of a Thiol Monolayer-Protected Gold Nanoparticle at $1.1 \AA$ A Resolution. Science 2007, 318, 430-433. [CrossRef]

21. Wang, S.; Li, Q.; Kang, X.; Zhu, M. Customizing the Structure, Composition, and Properties of Alloy Nanoclusters by Metal Exchange. Acc. Chem. Res. 2018, 51, 2784-2792. [CrossRef] [PubMed]

22. Higaki, T.; Li, Q.; Zhou, M.; Zhao, S.; Li, Y.; Li, S.; Jin, R. Toward the Tailoring Chemistry of Metal Nanoclusters for Enhancing Functionalities. Acc. Chem. Res. 2018, 51, 2764-2773. [CrossRef] [PubMed]

23. Negishi, Y.; Kurashige, W.; Niihori, Y.; Iwasa, T.; Nobusada, K. Isolation, Structure, and Stability of a Dodecanethiolate-Protected $\mathrm{Pd}_{1} \mathrm{Au}_{24}$ Cluster. Phys. Chem. Chem. Phys. 2010, 12, 6219-6225. [CrossRef]

24. Negishi, Y.; Iwai, T.; Ide, M. Continuous Modulation of Electronic Structure of Stable Thiolate-Protected $\mathrm{Au}_{25}$ Cluster by Ag Doping. Chem. Commun. 2010, 46, 4713-4715. [CrossRef] [PubMed]

25. Negishi, Y.; Igarashi, K.; Munakata, K.; Ohgake, W.; Nobusada, K. Palladium Doping of Magic Gold Cluster $\mathrm{Au}_{38}\left(\mathrm{SC}_{2} \mathrm{H}_{4} \mathrm{Ph}\right)_{24}$ : Formation of $\mathrm{Pd}_{2} \mathrm{Au}_{36}\left(\mathrm{SC}_{2} \mathrm{H}_{4} \mathrm{Ph}\right)_{24}$ with Higher Stability than $\mathrm{Au}_{38}\left(\mathrm{SC}_{2} \mathrm{H}_{4} \mathrm{Ph}\right)_{24}$. Chem. Commun. 2012, 48, 660-662. [CrossRef] [PubMed]

26. Negishi, Y.; Munakata, K.; Ohgake, W.; Nobusada, K. Effect of Copper Doping on Electronic Structure, Geometric Structure, and Stability of Thiolate-Protected $\mathrm{Au}_{25}$ Nanoclusters. J. Phys. Chem. Lett. 2012, 3, 2209-2214. [CrossRef]

27. Niihori, Y.; Kurashige, W.; Matsuzaki, M.; Negishi, Y. Remarkable Enhancement in Ligand-Exchange Reactivity of Thiolate-Protected $\mathrm{Au}_{25}$ Nanoclusters by Single Pd Atom Doping. Nanoscale 2013, 5, 508-512. [CrossRef]

28. Negishi, Y.; Kurashige, W.; Kobayashi, Y.; Yamazoe, S.; Kojima, N.; Seto, M.; Tsukuda, T. Formation of a $\mathrm{Pd} @ \mathrm{Au}_{12}$ Superatomic Core in $\mathrm{Au}_{24} \mathrm{Pd}_{1}\left(\mathrm{SC}_{12} \mathrm{H}_{25}\right){ }_{18}$ Probed by ${ }^{197} \mathrm{Au}$ Mössbauer and Pd K-edge EXAFS Spectroscopy. J. Phys. Chem. Lett. 2013, 4, 3579-3583. [CrossRef]

29. Negishi, Y.; Kurashige, W.; Niihori, Y.; Nobusada, K. Toward the Creation of Stable, Functionalized Metal Clusters. Phys. Chem. Chem. Phys. 2013, 15, 18736-18751. [CrossRef]

30. Niihori, Y.; Matsuzaki, M.; Uchida, C.; Negishi, Y. Advanced Use of High-Performance Liquid Chromatography for Synthesis of Controlled Metal Clusters. Nanoscale 2014, 6, 7889-7896. [CrossRef]

31. Yamazoe, S.; Kurashige, W.; Nobusada, K.; Negishi, Y.; Tsukuda, T. Preferential Location of Coinage Metal Dopants $(\mathrm{M}=\mathrm{Ag}$ or $\mathrm{Cu})$ in $\left[\mathrm{Au}_{25-x} \mathrm{M}_{x}\left(\mathrm{SC}_{2} \mathrm{H}_{4} \mathrm{Ph}\right)_{18}\right]^{-}(x \sim 1)$ as Determined by Extended X-ray Absorption Fine Structure and Density Functional Theory Calculations. J. Phys. Chem. C 2014, 118, 25284-25290. [CrossRef]

32. Sharma, S.; Kurashige, W.; Nobusada, K.; Negishi, Y. Effect of Trimetallization in Thiolate-Protected $\mathrm{Au}_{24-n} \mathrm{Cu}_{n}$ Pd Clusters. Nanoscale 2015, 7, 10606-10612. [CrossRef] [PubMed] 
33. Niihori, Y.; Eguro, M.; Kato, A.; Sharma, S.; Kumar, B.; Kurashige, W.; Nobusada, K.; Negishi, Y. Improvements in the Ligand-Exchange Reactivity of Phenylethanethiolate-Protected $\mathrm{Au}_{25}$ Nanocluster by $\mathrm{Ag}$ or $\mathrm{Cu}$ Incorporation. J. Phys. Chem. C 2016, 120, 14301-14309. [CrossRef]

34. Niihori, Y.; Hossain, S.; Kumar, B.; Nair, L.V.; Kurashige, W.; Negishi, Y. Perspective: Exchange Reactions in Thiolate-Protected Metal Clusters. APL Mater. 2017, 5, 053201. [CrossRef]

35. Niihori, Y.; Hossain, S.; Sharma, S.; Kumar, B.; Kurashige, W.; Negishi, Y. Understanding and Practical Use of Ligand and Metal Exchange Reactions in Thiolate-Protected Metal Clusters to Synthesize Controlled Metal Clusters. Chem. Rec. 2017, 17, 473-484. [CrossRef] [PubMed]

36. Niihori, Y.; Shima, D.; Yoshida, K.; Hamada, K.; Nair, L.V.; Hossain, S.; Kurashige, W.; Negishi, Y. High-Performance Liquid Chromatography Mass Spectrometry of Gold and Alloy Clusters Protected by Hydrophilic Thiolates. Nanoscale 2018, 10, 1641-1649. [CrossRef]

37. Hossain, S.; Ono, T.; Yoshioka, M.; Hu, G.; Hosoi, M.; Chen, Z.; Nair, L.V.; Niihori, Y.; Kurashige, W.; Jiang, D.-E.; et al. Thiolate-Protected Trimetallic $\mathrm{Au}_{\sim 20} \mathrm{Ag}_{\sim 4} \mathrm{Pd}$ and $\mathrm{Au}_{\sim 20} \mathrm{Ag}_{\sim 4} \mathrm{Pt}$ Alloy Clusters with Controlled Chemical Composition and Metal Positions. J. Phys. Chem. Lett. 2018, 9, 2590-2594. [CrossRef]

38. Yokoyama, T.; Hirata, N.; Tsunoyama, H.; Negishi, Y.; Nakajima, A. Characterization of Floating-gate Memory Device with Thiolate-Protected Gold and Gold-Palladium Nanoclusters. AIP Adv. 2018, 8, 065002. [CrossRef]

39. Niihori, Y.; Koyama, Y.; Watanabe, S.; Hashimoto, S.; Hossain, S.; Nair, L.V.; Kumar, B.; Kurashige, W.; Negishi, Y. Atomic and Isomeric Separation of Thiolate-Protected Alloy Clusters. J. Phys. Chem. Lett. 2018, 9, 4930-4934. [CrossRef]

40. Niihori, Y.; Hashimoto, S.; Koyama, Y.; Hossain, S.; Kurashige, W.; Negishi, Y. Dynamic Behavior of Thiolate-Protected Gold-Silver 38-Atom Alloy Clusters in Solution. J. Phys. Chem. C 2019, 123, 13324-13329. [CrossRef]

41. Kurashige, W.; Hayashi, R.; Wakamatsu, K.; Kataoka, Y.; Hossain, S.; Iwase, A.; Kudo, A.; Yamazoe, S.; Negishi, Y. Atomic-Level Understanding of the Effect of Heteroatom Doping of the Cocatalyst on Water-Splitting Activity in AuPd or AuPt Alloy Cluster-Loaded $\mathrm{BaLa}_{4} \mathrm{Ti}_{4} \mathrm{O}_{15}$. ACS Appl. Energy Mater. 2019, 2, 4175-4187. [CrossRef]

42. Hossain, S.; Imai, Y.; Suzuki, D.; Choi, W.; Chen, Z.; Suzuki, T.; Yoshioka, M.; Kawawaki, T.; Lee, D.; Negishi, Y. Elucidating Ligand Effects in Thiolate-Protected Metal Clusters Using $\mathrm{Au}_{24} \mathrm{Pt}(\mathrm{TBBT})_{18}$ as a Model Cluster. Nanoscale 2019, 11, 22089-22098. [CrossRef] [PubMed]

43. Kawawaki, T.; Negishi, Y.; Kawasaki, H. Photo/electrocatalysis and Photosensitization Using Metal Nanoclusters for Green Energy and Medical Applications. Nanoscale Adv. 2020, 2, 17-36. [CrossRef]

44. Hossain, S.; Imai, Y.; Motohashi, Y.; Chen, Z.; Suzuki, D.; Suzuki, T.; Kataoka, Y.; Hirata, M.; Ono, T.; Kurashige, W.; et al. Understanding and Designing One-Dimensional Assemblies of Ligand-Protected Metal Nanoclusters. Mater. Horiz.. in press. [CrossRef]

45. Haruta, M. Spiers Memorial Lecture Role of Perimeter Interfaces in Catalysis by Gold Nanoparticles. Faraday Discuss. 2011, 152, 11-32. [CrossRef] [PubMed]

46. Nie, X.; Qian, H.; Ge, Q.; Xu, H.; Jin, R. CO Oxidation Catalyzed by Oxide-Supported $\mathrm{Au}_{25}(\mathrm{SR})_{18}$ Nanoclusters and Identification of Perimeter Sites as Active Centers. ACS Nano 2012, 6, 6014-6022. [CrossRef]

47. Nie, X.; Zeng, C.; Ma, X.; Qian, H.; Ge, Q.; Xu, H.; Jin, R. $\mathrm{CeO}_{2}$-Supported $\mathrm{Au}_{38}(\mathrm{SR})_{24}$ Nanocluster Catalysts for CO Oxidation: A Comparison of Ligand-on and -off Catalysts. Nanoscale 2013, 5, 5912-5918. [CrossRef]

48. Wu, Z.; Jiang, D.-e.; Mann, A.K.P.; Mullins, D.R.; Qiao, Z.-A.; Allard, L.F.; Zeng, C.; Jin, R.; Overbury, S.H. Thiolate Ligands as a Double-Edged Sword for CO Oxidation on $\mathrm{CeO}_{2}$ Supported $\mathrm{Au}_{25}\left(\mathrm{SCH}_{2} \mathrm{CH}_{2} \mathrm{Ph}\right)_{18}$ Nanoclusters. J. Am. Chem. Soc. 2014, 136, 6111-6122. [CrossRef]

49. Li, W.; Ge, Q.; Ma, X.; Chen, Y.; Zhu, M.; Xu, H.; Jin, R. Mild Activation of $\mathrm{CeO}_{2}$-Supported Gold Nanoclusters and Insight into the Catalytic Behavior in CO Oxidation. Nanoscale 2016, 8, 2378-2385. [CrossRef]

50. Gaur, S.; Miller, J.T.; Stellwagen, D.; Sanampudi, A.; Kumar, C.S.S.R.; Spivey, J.J. Synthesis, Characterization, and Testing of Supported Au Catalysts Prepared from Atomically-Tailored $\mathrm{Au}_{38}\left(\mathrm{SC}_{12} \mathrm{H}_{25}\right)_{24}$ Clusters. Phys. Chem. Chem. Phys. 2012, 14, 1627-1634. [CrossRef]

51. Wu, Z.; Hu, G.; Jiang, D.-e.; Mullins, D.R.; Zhang, Q.-F.; Allard, L.F.; Wang, L.-S.; Overbury, S.H. Diphosphine-Protected $\mathrm{Au}_{22}$ Nanoclusters on Oxide Supports Are Active for Gas-Phase Catalysis without Ligand Removal. Nano Lett. 2016, 16, 6560-6567. [CrossRef] 
52. Wu, Z.; Mullins, D.R.; Allard, L.F.; Zhang, Q.; Wang, L. CO Oxidation over Ceria Supported $\mathrm{Au}_{22}$ Nanoclusters: Shape Effect of the Support. Chin. Chem. Lett. 2018, 29, 795-799. [CrossRef]

53. Lin, J.; Li, W.; Liu, C.; Huang, P.; Zhu, M.; Ge, Q.; Li, G. One-Phase Controlled Synthesis of Au 25 Nanospheres and Nanorods from $1.3 \mathrm{~nm} \mathrm{Au}: \mathrm{PPh}_{3}$ Nanoparticles: The Ligand Effects. Nanoscale 2015, 7, 13663-13670. [CrossRef] [PubMed]

54. Li, W.; Liu, C.; Abroshan, H.; Ge, Q.; Yang, X.; Xu, H.; Li, G. Catalytic CO Oxidation Using Bimetallic $\mathrm{M}_{X} \mathrm{Au}_{25-X}$ Clusters: A Combined Experimental and Computational Study on Doping Effects. J. Phys. Chem. C 2016, 120, 10261-10267. [CrossRef]

55. Good, J.; Duchesne, P.N.; Zhang, P.; Koshut, W.; Zhou, M.; Jin, R. On the Functional Role of the Cerium Oxide Support in the $\mathrm{Au}_{38}(\mathrm{SR})_{24} / \mathrm{CeO}_{2}$ Catalyst for CO Oxidation. Catal. Today 2017, 280, 239-245. [CrossRef]

56. Du, Y.; Sheng, H.; Astruc, D.; Zhu, M. Atomically Precise Noble Metal Nanoclusters as Efficient Catalysts: A Bridge between Structure and Properties. Chem. Rev. 2020, 120, 526-622. [CrossRef]

57. Xie, S.; Tsunoyama, H.; Kurashige, W.; Negishi, Y.; Tsukuda, T. Enhancement in Aerobic Alcohol Oxidation Catalysis of $\mathrm{Au}_{25}$ Clusters by Single Pd Atom Doping. ACS Catal. 2012, 2, 1519-1523. [CrossRef]

58. Yoskamtorn, T.; Yamazoe, S.; Takahata, R.; Nishigaki, J.-i.; Thivasasith, A.; Limtrakul, J.; Tsukuda, T. Thiolate-Mediated Selectivity Control in Aerobic Alcohol Oxidation by Porous Carbon-Supported $\mathrm{Au}_{25}$ Clusters. ACS Catal. 2014, 4, 3696-3700. [CrossRef]

59. Lavenn, C.; Demessence, A.; Tuel, A. $\mathrm{Au}_{25}\left(\mathrm{SPh}-\mathrm{pNH}_{2}\right)_{17}$ Nanoclusters Deposited on SBA-15 as Catalysts for Aerobic Benzyl Alcohol Oxidation. J. Catal. 2015, 322, 130-138. [CrossRef]

60. Deng, H.; Wang, S.; Jin, S.; Yang, S.; Xu, Y.; Liu, L.; Xiang, J.; Hu, D.; Zhu, M. Active Metal (Cadmium) Doping Enhanced the Stability of Inert Metal (Gold) Nanocluster under $\mathrm{O}_{2}$ Atmosphere and the Catalysis Activity of Benzyl Alcohol Oxidation. Gold Bull. 2015, 48, 161-167. [CrossRef]

61. Li, L.; Dou, L.; Zhang, H. Layered Double Hydroxide Supported Gold Nanoclusters by Glutathione-Capped Au Nanoclusters Precursor Method for Highly Efficient Aerobic Oxidation of Alcohols. Nanoscale 2014, 6, 3753-3763. [CrossRef] [PubMed]

62. Wang, S.; Yin, S.; Chen, G.; Li, L.; Zhang, H. Nearly Atomic Precise Gold Nanoclusters on Nickel-Based Layered Double Hydroxides for Extraordinarily Efficient Aerobic Oxidation of Alcohols. Catal. Sci. Technol. 2016, 6, 4090-4104. [CrossRef]

63. Yin, S.; Li, J.; Zhang, H. Hierarchical Hollow Nanostructured Core@Shell Recyclable Catalysts $\gamma-\mathrm{Fe}_{2} \mathrm{O}_{3} @ \mathrm{LDH} @ \mathrm{Au}_{25-X}$ for Highly Efficient Alcohol Oxidation. Green Chem. 2016, 18, 5900-5914. [CrossRef]

64. Lee, K.E.; Shivhare, A.; Hu, Y.; Scott, R.W.J. Supported Bimetallic AuPd Clusters Using Activated Au 25 Clusters. Catal. Today 2017, 280, 259-265. [CrossRef]

65. Tsunoyama, H.; Ichikuni, N.; Sakurai, H.; Tsukuda, T. Effect of Electronic Structures of Au Clusters Stabilized by Poly(N-vinyl-2-pyrrolidone) on Aerobic Oxidation Catalysis. J. Am. Chem. Soc. 2009, 131, 7086-7093. [CrossRef]

66. Zhu, Y.; Qian, H.; Zhu, M.; Jin, R. Thiolate-Protected $\mathrm{Au}_{n}$ Nanoclusters as Catalysts for Selective Oxidation and Hydrogenation Processes. Adv. Mater. 2010, 22, 1915-1920. [CrossRef]

67. Zhu, Y.; Qian, H.; Jin, R. An Atomic-Level Strategy for Unraveling Gold Nanocatalysis from the Perspective of $\mathrm{Au}_{n}(\mathrm{SR})_{m}$ Nanoclusters. Chem. Eur. J. 2010, 16, 11455-11462. [CrossRef]

68. Wang, S.; Jin, S.; Yang, S.; Chen, S.; Song, Y.; Zhang, J.; Zhu, M. Total Structure Determination of Surface Doping $\left[\mathrm{Ag}_{46} \mathrm{Au}_{24}(\mathrm{SR})_{32}\right]\left(\mathrm{BPh}_{4}\right)_{2}$ Nanocluster and Its Structure-Related Catalytic Property. Science Adv. 2015, 1, e1500441. [CrossRef]

69. Chai, J.; Chong, H.; Wang, S.; Yang, S.; Wu, M.; Zhu, M. Controlling the Selectivity of Catalytic Oxidation of Styrene over Nanocluster Catalysts. RSC Adv. 2016, 6, 111399-111405. [CrossRef]

70. Turner, M.; Golovko, V.B.; Vaughan, O.P.H.; Abdulkin, P.; Berenguer-Murcia, A.; Tikhov, M.S.; Johnson, B.F.G.; Lambert, R.M. Selective Oxidation with Dioxygen by Gold Nanoparticle Catalysts Derived from 55-Atom Clusters. Nature 2008, 454, 981-983. [CrossRef]

71. Zhang, B.; Kaziz, S.; Li, H.; Hevia, M.G.; Wodka, D.; Mazet, C.; Bürgi, T.; Barrabés, N. Modulation of Active Sites in Supported $\mathrm{Au}_{38}\left(\mathrm{SC}_{2} \mathrm{H}_{4} \mathrm{Ph}\right)_{24}$ Cluster Catalysts: Effect of Atmosphere and Support Material. J. Phys. Chem. C 2015, 119, 11193-11199. [CrossRef]

72. Liu, Y.; Tsunoyama, H.; Akita, T.; Xie, S.; Tsukuda, T. Aerobic Oxidation of Cyclohexane Catalyzed by Size-Controlled Au Clusters on Hydroxyapatite: Size Effect in the Sub-2 nm Regime. ACS Catal. 2011, 1, 2-6. [CrossRef] 
73. Liu, C.; Yan, C.; Lin, J.; Yu, C.; Huang, J.; Li, G. One-Pot Synthesis of $\mathrm{Au}_{144}\left(\mathrm{SCH}_{2} \mathrm{Ph}\right)_{60}$ Nanoclusters and Their Catalytic Application. J. Mater. Chem. A 2015, 3, 20167-20173. [CrossRef]

74. Li, G.; Qian, H.; Jin, R. Gold Nanocluster-Catalyzed Selective Oxidation of Sulfide to Sulfoxide. Nanoscale 2012, 4, 6714-6717. [CrossRef]

75. Chen, Y.; Wang, J.; Liu, C.; Li, Z.; Li, G. Kinetically Controlled Synthesis of $\mathrm{Au}_{102}(\mathrm{SPh})_{44}$ Nanoclusters and Catalytic Application. Nanoscale 2016, 8, 10059-10065. [CrossRef] [PubMed]

76. Kauffman, D.R.; Alfonso, D.; Matranga, C.; Ohodnicki, P.; Deng, X.; Siva, R.C.; Zeng, C.; Jin, R. Probing Active Site Chemistry with Differently Charged $\mathrm{Au}_{25}{ }^{q}$ Nanoclusters $(q=-1,0,+1)$. Chem. Sci. 2014, 5, 3151-3157. [CrossRef]

77. Kauffman, D.R.; Alfonso, D.; Matranga, C.; Qian, H.; Jin, R. Experimental and Computational Investigation of $\mathrm{Au}_{25}$ Clusters and $\mathrm{CO}_{2}$ : A Unique Interaction and Enhanced Electrocatalytic Activity. J. Am. Chem. Soc. 2012, 134, 10237-10243. [CrossRef]

78. Zhao, S.; Jin, R.; Jin, R. Opportunities and Challenges in $\mathrm{CO}_{2}$ Reduction by Gold- and Silver-Based Electrocatalysts: From Bulk Metals to Nanoparticles and Atomically Precise Nanoclusters. ACS Energy Lett. 2018, 3, 452-462. [CrossRef]

79. Andrews, E.; Katla, S.; Kumar, C.; Patterson, M.; Sprunger, P.; Flake, J. Electrocatalytic Reduction of $\mathrm{CO}_{2}$ at Au Nanoparticle Electrodes: Effects of Interfacial Chemistry on Reduction Behavior. J. Electrochem. Soc. 2015, 162, F1373-F1378. [CrossRef]

80. Kauffman, D.R.; Thakkar, J.; Siva, R.; Matranga, C.; Ohodnicki, P.R.; Zeng, C.; Jin, R. Efficient Electrochemical $\mathrm{CO}_{2}$ Conversion Powered by Renewable Energy. ACS Appl. Mater. Inter. 2015, 7, 15626-15632. [CrossRef]

81. Zhao, S.; Austin, N.; Li, M.; Song, Y.; House, S.D.; Bernhard, S.; Yang, J.C.; Mpourmpakis, G.; Jin, R. Influence of Atomic-Level Morphology on Catalysis: The Case of Sphere and Rod-Like Gold Nanoclusters for $\mathrm{CO}_{2}$ Electroreduction. ACS Catal. 2018, 8, 4996-5001. [CrossRef]

82. Jupally, V.R.; Dharmaratne, A.C.; Crasto, D.; Huckaba, A.J.; Kumara, C.; Nimmala, P.R.; Kothalawala, N.; Delcamp, J.H.; Dass, A. $\mathrm{Au}_{137}(\mathrm{SR})_{56}$ Nanomolecules: Composition, Optical Spectroscopy, Electrochemistry and Electrocatalytic Reduction of $\mathrm{CO}_{2}$. Chem. Commun. 2014, 50, 9895-9898. [CrossRef] [PubMed]

83. Alfonso, D.R.; Kauffman, D.; Matranga, C. Active Sites of Ligand-Protected $\mathrm{Au}_{25}$ Nanoparticle Catalysts for $\mathrm{CO}_{2}$ Electroreduction to CO. J. Chem. Phys. 2016, 144, 184705. [CrossRef] [PubMed]

84. Seh, Z.W.; Kibsgaard, J.; Dickens, C.F.; Chorkendorff, I.; Nørskov, J.K.; Jaramillo, T.F. Combining Theory and Experiment in Electrocatalysis: Insights into Materials Design. Science 2017, 355, eaad4998. [CrossRef] [PubMed]

85. Jiao, Y.; Zheng, Y.; Jaroniec, M.; Qiao, S.Z. Design of Electrocatalysts for Oxygen- and Hydrogen-Involving Energy Conversion Reactions. Chem. Soc. Rev. 2015, 44, 2060-2086. [CrossRef]

86. Sabatier, P. Hydrogénations Et Déshydrogénations Par Catalyse. Ber. Dtsch. Chem. Ges. 1911, 44, $1984-2001$. [CrossRef]

87. Parsons, R. The Rate of Electrolytic Hydrogen Evolution and the Heat of Adsorption of Hydrogen. Trans. Faraday Soc. 1958, 54, 1053-1063. [CrossRef]

88. Benck, J.D.; Hellstern, T.R.; Kibsgaard, J.; Chakthranont, P.; Jaramillo, T.F. Catalyzing the Hydrogen Evolution Reaction (HER) with Molybdenum Sulfide Nanomaterials. ACS Catal. 2014, 4, 3957-3971. [CrossRef]

89. Jaramillo, T.F.; Jørgensen, K.P.; Bonde, J.; Nielsen, J.H.; Horch, S.; Chorkendorff, I. Identification of Active Edge Sites for Electrochemical $\mathrm{H}_{2}$ Evolution from $\mathrm{MoS}_{2}$ Nanocatalysts. Science 2007, 317, 100-102. [CrossRef]

90. Cao, B.; Veith, G.M.; Neuefeind, J.C.; Adzic, R.R.; Khalifah, P.G. Mixed Close-Packed Cobalt Molybdenum Nitrides as Non-Noble Metal Electrocatalysts for the Hydrogen Evolution Reaction. J. Am. Chem. Soc. 2013, 135, 19186-19192. [CrossRef]

91. Popczun, E.J.; McKone, J.R.; Read, C.G.; Biacchi, A.J.; Wiltrout, A.M.; Lewis, N.S.; Schaak, R.E. Nanostructured Nickel Phosphide as an Electrocatalyst for the Hydrogen Evolution Reaction. J. Am. Chem. Soc. 2013, 135, 9267-9270. [CrossRef] [PubMed]

92. Kibler, L.A.; El-Aziz, A.M.; Hoyer, R.; Kolb, D.M. Tuning Reaction Rates by Lateral Strain in a Palladium Monolayer. Angew. Chem. Int. Ed. 2005, 44, 2080-2084. [CrossRef] [PubMed]

93. McCrory, C.C.L.; Jung, S.; Peters, J.C.; Jaramillo, T.F. Benchmarking Heterogeneous Electrocatalysts for the Oxygen Evolution Reaction. J. Am. Chem. Soc. 2013, 135, 16977-16987. [CrossRef] [PubMed]

94. Stoerzinger, K.A.; Qiao, L.; Biegalski, M.D.; Shao-Horn, Y. Orientation-Dependent Oxygen Evolution Activities of Rutile $\mathrm{IrO}_{2}$ and $\mathrm{RuO}_{2}$. J. Phys. Chem. Lett. 2014, 5, 1636-1641. [CrossRef] [PubMed] 
95. Zhang, B.; Zheng, X.; Voznyy, O.; Comin, R.; Bajdich, M.; García-Melchor, M.; Han, L.; Xu, J.; Liu, M.; Zheng, L.; et al. Homogeneously Dispersed Multimetal Oxygen-Evolving Catalysts. Science 2016, 352, 333-337. [CrossRef] [PubMed]

96. Gasteiger, H.A.; Kocha, S.S.; Sompalli, B.; Wagner, F.T. Activity Benchmarks and Requirements for Pt, Pt-Alloy, and Non-Pt Oxygen Reduction Catalysts for PEMFCs. Appl. Catal. B 2005, 56, 9-35. [CrossRef]

97. Gasteiger, H.A.; Marković, N.M. Just a Dream-or Future Reality? Science 2009, 324, 48-49. [CrossRef]

98. Siahrostami, S.; Verdaguer-Casadevall, A.; Karamad, M.; Deiana, D.; Malacrida, P.; Wickman, B.; Escudero-Escribano, M.; Paoli, E.A.; Frydendal, R.; Hansen, T.W.; et al. Enabling Direct $\mathrm{H}_{2} \mathrm{O}_{2}$ Production through Rational Electrocatalyst Design. Nat. Mater. 2013, 12, 1137-1143. [CrossRef]

99. Nørskov, J.K.; Rossmeisl, J.; Logadottir, A.; Lindqvist, L.; Kitchin, J.R.; Bligaard, T.; Jónsson, H. Origin of the Overpotential for Oxygen Reduction at a Fuel-Cell Cathode. J. Phys. Chem. B 2004, 108, 17886-17892. [CrossRef]

100. Huang, X.; Zhao, Z.; Cao, L.; Chen, Y.; Zhu, E.; Lin, Z.; Li, M.; Yan, A.; Zettl, A.; Wang, Y.M.; et al. High-Performance Transition Metal-Doped $\mathrm{Pt}_{3} \mathrm{Ni}$ Octahedra for Oxygen Reduction Reaction. Science 2015, 348, 1230-1234. [CrossRef]

101. Peng, Z.; Yang, H. Synthesis and Oxygen Reduction Electrocatalytic Property of Pt-on-Pd Bimetallic Heteronanostructures. J. Am. Chem. Soc. 2009, 131, 7542-7543. [CrossRef] [PubMed]

102. Kwak, K.; Choi, W.; Tang, Q.; Kim, M.; Lee, Y.; Jiang, D.-e.; Lee, D. A Molecule-Like PtAu ${ }_{24}\left(\mathrm{SC}_{6} \mathrm{H}_{13}\right)_{18}$ Nanocluster as an Electrocatalyst for Hydrogen Production. Nat. Commun. 2017, 8, 14723. [CrossRef] [PubMed]

103. Choi, W.; Hu, G.; Kwak, K.; Kim, M.; Jiang, D.-e.; Choi, J.-P.; Lee, D. Effects of Metal-Doping on Hydrogen Evolution Reaction Catalyzed by $\mathrm{MAu}_{24}$ and $\mathrm{M}_{2} \mathrm{Au}_{36}$ Nanoclusters $(\mathrm{M}=\mathrm{Pt}, \mathrm{Pd})$. ACS Appl. Mater. Inter. 2018, 10, 44645-44653. [CrossRef] [PubMed]

104. Kwak, K.; Lee, D. Electrochemistry of Atomically Precise Metal Nanoclusters. Acc. Chem. Res. 2019, 52, 12-22. [CrossRef] [PubMed]

105. Hu, G.; Tang, Q.; Lee, D.; Wu, Z.; Jiang, D.-e. Metallic Hydrogen in Atomically Precise Gold Nanoclusters. Chem. Mater. 2017, 29, 4840-4847. [CrossRef]

106. Du, Y.; Xiang, J.; Ni, K.; Yun, Y.; Sun, G.; Yuan, X.; Sheng, H.; Zhu, Y.; Zhu, M. Design of Atomically Precise $\mathrm{Au}_{2} \mathrm{Pd}_{6}$ Nanoclusters for Boosting Electrocatalytic Hydrogen Evolution on $\mathrm{MoS}_{2}$. Inorg. Chem. Front. 2018, 5, 2948-2954. [CrossRef]

107. Eguchi, D.; Sakamoto, M.; Teranishi, T. Ligand Effect on the Catalytic Activity of Porphyrin-Protected Gold Clusters in the Electrochemical Hydrogen Evolution Reaction. Chem. Sci. 2018, 9, 261-265. [CrossRef]

108. Zhao, S.; Jin, R.; Song, Y.; Zhang, H.; House, S.D.; Yang, J.C.; Jin, R. Atomically Precise Gold Nanoclusters Accelerate Hydrogen Evolution over $\mathrm{MoS}_{2}$ Nanosheets: The Dual Interfacial Effect. Small 2017, 13, 1701519. [CrossRef]

109. Kwak, K.; Choi, W.; Tang, Q.; Jiang, D.-e.; Lee, D. Rationally Designed Metal Nanocluster for Electrocatalytic Hydrogen Production from Water. J. Mater. Chem. A 2018, 6, 19495-19501. [CrossRef]

110. Zhao, S.; Jin, R.; Abroshan, H.; Zeng, C.; Zhang, H.; House, S.D.; Gottlieb, E.; Kim, H.J.; Yang, J.C.; Jin, R. Gold Nanoclusters Promote Electrocatalytic Water Oxidation at the Nanocluster/CoSe $\mathrm{I}_{2}$ Interface. J. Am. Chem. Soc. 2017, 139, 1077-1080. [CrossRef]

111. Chen, W.; Chen, S. Oxygen Electroreduction Catalyzed by Gold Nanoclusters: Strong Core Size Effects. Angew. Chem. Int. Ed. 2009, 48, 4386-4389. [CrossRef] [PubMed]

112. Wang, L.; Tang, Z.; Yan, W.; Yang, H.; Wang, Q.; Chen, S. Porous Carbon-Supported Gold Nanoparticles for Oxygen Reduction Reaction: Effects of Nanoparticle Size. ACS Appl. Mater. Inter. 2016, 8, 20635-20641. [CrossRef] [PubMed]

113. Sumner, L.; Sakthivel, N.A.; Schrock, H.; Artyushkova, K.; Dass, A.; Chakraborty, S. Electrocatalytic Oxygen Reduction Activities of Thiol-Protected Nanomolecules Ranging in Size from $\mathrm{Au}_{28}(\mathrm{SR})_{20}$ to $\mathrm{Au}_{279}(\mathrm{SR})_{84}$. J. Phys. Chem. C 2018, 122, 24809-24817. [CrossRef]

114. Jones, T.C.; Sumner, L.; Ramakrishna, G.; Hatshan, M.b.; Abuhagr, A.; Chakraborty, S.; Dass, A. Bulky t-Butyl Thiolated Gold Nanomolecular Series: Synthesis, Characterization, Optical Properties, and Electrocatalysis. J. Phys. Chem. C 2018, 122, 17726-17737. [CrossRef] 
115. Lu, Y.; Jiang, Y.; Gao, X.; Chen, W. Charge State-Dependent Catalytic Activity of $\left[\mathrm{Au}_{25}\left(\mathrm{SC}_{12} \mathrm{H}_{25}\right)_{18}\right]$ Nanoclusters for the Two-Electron Reduction of Dioxygen to Hydrogen Peroxide. Chem. Commun. 2014, 50, 8464-8467. [CrossRef]

116. Kwak, K.; Azad, U.P.; Choi, W.; Pyo, K.; Jang, M.; Lee, D. Efficient Oxygen Reduction Electrocatalysts Based on Gold Nanocluster-Graphene Composites. ChemElectroChem 2016, 3, 1253-1260. [CrossRef]

117. Skúlason, E.; Tripkovic, V.; Björketun, M.E.; Gudmundsdóttir, S.; Karlberg, G.; Rossmeisl, J.; Bligaard, T.; Jónsson, H.; Nørskov, J.K. Modeling the Electrochemical Hydrogen Oxidation and Evolution Reactions on the Basis of Density Functional Theory Calculations. J. Phys. Chem. C 2010, 114, 18182-18197. [CrossRef]

118. Sakamoto, M.; Tanaka, D.; Tsunoyama, H.; Tsukuda, T.; Minagawa, Y.; Majima, Y.; Teranishi, T. Platonic Hexahedron Composed of Six Organic Faces with an Inscribed Au Cluster. J. Am. Chem. Soc. 2012, 134, 816-819. [CrossRef]

119. Tanaka, D.; Inuta, Y.; Sakamoto, M.; Furube, A.; Haruta, M.; So, Y.-G.; Kimoto, K.; Hamada, I.; Teranishi, T. Strongest П-Metal Orbital Coupling in a Porphyrin/Gold Cluster System. Chem. Sci. 2014, 5, 2007-2010. [CrossRef]

120. Li, P.; Wang, M.; Duan, X.; Zheng, L.; Cheng, X.; Zhang, Y.; Kuang, Y.; Li, Y.; Ma, Q.; Feng, Z.; et al. Boosting Oxygen Evolution of Single-Atomic Ruthenium through Electronic Coupling with Cobalt-Iron Layered Double Hydroxides. Nat. Commun. 2019, 10, 1711. [CrossRef]

121. Lee, Y.; Suntivich, J.; May, K.J.; Perry, E.E.; Shao-Horn, Y. Synthesis and Activities of Rutile $\mathrm{IrO}_{2}$ and $\mathrm{RuO}_{2}$ Nanoparticles for Oxygen Evolution in Acid and Alkaline Solutions. J. Phys. Chem. Lett. 2012, 3, 399-404. [CrossRef] [PubMed]

122. Mattioli, G.; Giannozzi, P.; Amore Bonapasta, A.; Guidoni, L. Reaction Pathways for Oxygen Evolution Promoted by Cobalt Catalyst. J. Am. Chem. Soc. 2013, 135, 15353-15363. [CrossRef] [PubMed]

123. Frydendal, R.; Paoli, E.A.; Knudsen, B.P.; Wickman, B.; Malacrida, P.; Stephens, I.E.L.; Chorkendorff, I. Benchmarking the Stability of Oxygen Evolution Reaction Catalysts: The Importance of Monitoring Mass Losses. ChemElectroChem 2014, 1, 2075-2081. [CrossRef]

124. Zhuang, Z.; Sheng, W.; Yan, Y. Synthesis of Monodispere $\mathrm{Au} @ \mathrm{Co}_{3} \mathrm{O}_{4}$ Core-Shell Nanocrystals and Their Enhanced Catalytic Activity for Oxygen Evolution Reaction. Adv. Mater. 2014, 26, 3950-3955. [CrossRef]

125. Zhao, X.; Gao, P.; Yan, Y.; Li, X.; Xing, Y.; Li, H.; Peng, Z.; Yang, J.; Zeng, J. Gold Atom-Decorated $\mathrm{CoSe}_{2}$ Nanobelts with Engineered Active Sites for Enhanced Oxygen Evolution. J. Mater. Chem. A 2017, 5, 20202-20207. [CrossRef]

126. Li, Z.-y.; Ye, K.-h.; Zhong, Q.-s.; Zhang, C.-j.; Shi, S.-t.; Xu, C.-w. Au- $\mathrm{Co}_{3} \mathrm{O}_{4} / \mathrm{C}$ as an Efficient Electrocatalyst for the Oxygen Evolution Reaction. ChemPlusChem 2014, 79, 1569-1572. [CrossRef]

127. Mills, G.; Gordon, M.S.; Metiu, H. Oxygen Adsorption on Au Clusters and a Rough Au(111) Surface: The Role of Surface Flatness, Electron Confinement, Excess Electrons, and Band Gap. J. Chem. Phys. 2003, 118, 4198-4205. [CrossRef]

128. Okumura, M.; Kitagawa, Y.; Kawakami, T.; Haruta, M. Theoretical Investigation of the Hetero-Junction Effect in PVP-Stabilized $\mathrm{Au}_{13}$ Clusters. The Role of PVP in Their Catalytic Activities. Chem. Phys. Lett. 2008, 459, 133-136. [CrossRef]

129. Yin, H.; Tang, H.; Wang, D.; Gao, Y.; Tang, Z. Facile Synthesis of Surfactant-Free Au Cluster/Graphene Hybrids for High-Performance Oxygen Reduction Reaction. ACS Nano 2012, 6, 8288-8297. [CrossRef]

(C) 2020 by the authors. Licensee MDPI, Basel, Switzerland. This article is an open access article distributed under the terms and conditions of the Creative Commons Attribution (CC BY) license (http://creativecommons.org/licenses/by/4.0/). 